\title{
EU banks after the crisis: sinners in the hands of angry markets
}

\author{
Antonio Sánchez Serrano ${ }^{1}$ \\ European Systemic Risk Board \\ antonio.sanchez@esrb.europa.eu
}

\begin{abstract}
European Union banks were severely hit by the global financial crisis in 2008 and their stock prices and returns have generally not recovered since then, differently to what has been observed in other sectors (i.e., non-financial corporations) and jurisdictions (i.e., US). In this paper, we focus on three episodes of financial turmoil in EU financial markets occurring after the global financial crisis (August 2015, December 2015 and January 2016, and June 2016) and, through a series of linear regressions, with and without control variables, attempt to determine the common features of those banks which stock returns declined the most. Results of the regressions tend to suggest that size has been driving the decreases in stock returns in the three episodes. Regarding asset quality, the Texas ratio has been a decisive factor in the evolution of stock returns of EU banks in the second and third periods. Interestingly, profitability variables seem not to be statistically significant to explain the declines in stock returns, except in the third period, but only under some specifications. An evolution on the perception by financial market participants on EU banks, with a larger importance on asset quality in the latter periods, can also be observed. Lastly, on the basis of these results, further policy actions would be needed to clean-up the balance sheet of banks, as a necessary step towards full recovery after the global financial crisis.
\end{abstract}

JEL Classification: G12, G14, G32, G21

Keywords: European banks, stock returns, asset quality, profitability, global financial crisis

"[the Devil]... stands waiting for them, like greedy hungry lions that see their prey, and expect to have it..."

Sinners in the Hands of an Angry God

Jonathan Edwards, 1741

Corresponding author. Sonnemannstrasse 22, 60314 Frankfurt am Main, Germany. Phone number: +49 691344 4446. Fax: +49 691344935360. 


\section{INTRODUCTION}

European Union (EU) banks have been particularly hit by the global financial crisis. Unlike their peers in the US, there have been ongoing and continuous concerns on the sustainability of the EU banking system (International Monetary Fund, 2016), which have driven equity prices of European banks further down. Actually, equity prices of European banks are, in many cases, below their levels in 2008 (Figure 1). Weigand (2016) analyses in detail the evolution of EU, US and Japanese banks before, during and after the global financial crisis, and highlights the negative evolution of stock returns globally, and in particular in the case of EU and Japanese banks. In comparison with the evolution of the overall indexes of stock markets, EU banks seem to be among the worst performers, with a widening gap between bank stocks and indexes observed since 2012. Even in the aftermath of the global financial crisis (from mid-2012 onwards), EU banks were still subject to sharp, and usually short-lived, episodes of decreases in stock prices and returns, which were not mirrored by other EU listed corporations or by US banks. Like the sinners in the sermon by Jonathan Edwards (1741), EU banks seem to have been the prey of investors, which, almost ten years after the start of the global financial crisis, still perceive them as weak (thus, as an easy prey).

Figure 1.

Evolution of the EuroStoxx 50 and of the stock prices of a sample of EU banks (2 January $2008=100$ )

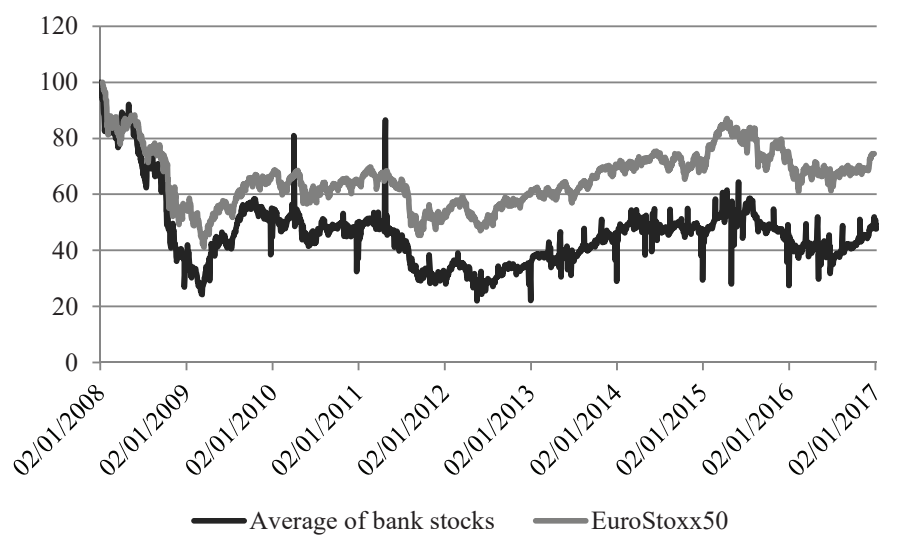

Notes: For the bank stock prices, the unweighted average of daily indexed stock prices of a sample of large EU banking groups is calculated, regardless of the stock markets where they are listed. Outliers signal days when some, but not all, financial markets in Europe were closed due to holidays.

Source: Bloomberg and author's calculations.

This paper focuses on three of the above-mentioned episodes of financial turmoil in European equity markets, which particularly affected bank stock prices and returns. These episodes took place in (i) August 2015, (ii) December 2015 and January 2016, and (iii) June 2016. August 2015 has been chosen because it was not particularly focused on banks. In the second period, comprising December 2015 and January 2016, concerns of market participants focused mostly on EU banks, with other stocks showing a less negative evolution. Finally, the third period should reflect the outcome of the UK vote regarding its EU membership, which, again, negatively affected banks across the EU. It is important to note that the three periods fall outside the global financial crisis, as an important contribution of this paper is to show how, even in the recovery phase from the global financial crisis, EU banks were still subject to intense pressure by market participants.

This paper takes a strong empirical approach and tries to identify which variables can explain why some banks saw their stock returns fell more sharply than others. The approach taken is purposely simple and departs from complex theoretical models; the idea of developing a general model for equity pricing falls clearly outside the scope of this paper. On the contrary, by using a series of linear regressions based on bank-specific variables, the paper aims at identifying 
common characteristics among the banks which saw their stock returns decline the most, in a context where the global financial crisis was already behind them.

The main input of this paper to the literature relates to the bank-specific variables which could explain stock performance of banks. As the paper is focused on three periods, it is also linked to the literature on event studies of equity performance. Differently to the majority of recent papers, the focus here is on three short episodes after the global financial crisis, not during the global financial crisis itself. Additionally, the paper can contribute to the literature stream looking at market sentiment and investor demand, in particular to the evolution of these two concepts in short periods of time (the three periods under consideration in the paper occur in less than one calendar year). Lastly, the results of the paper can also have practical implications for policymaking for banks in the EU.

The paper is organised as follows. A literature review is presented in Section 2, with the objective of setting the basis for the research carried out later in this paper. Methodology and data are described in Section 3 while results are discussed in Section 4. Section 5 concludes. An appendix with the detailed results of the regressions is included as well.

\section{LITERATURE REVIEW}

\subsection{Main theories on the determination of stock prices}

In general terms, stock prices are determined, as almost every price in economics, at the place where supply meets demand. In the case of shares, the number of shares (supply) is fixed ${ }^{2}$, so movements in the equity prices are responding mostly to changes in the demand side. Among the main drivers of the demand for a particular stock, information on future cash-flows, market sentiment, long-term trends and seasonal behaviour are usually mentioned. While not having the objective of being exhaustive on a topic about which a rich academic literature exists, the following paragraphs will briefly describe the main arguments of the efficient market hypothesis, the discounted cash-flows models and behavioural finance.

According to the efficient markets hypothesis (EMH), stock prices always incorporate all the available information about the underlying entity and hence changes in prices can only be explained due to new information of relevance to the stock price. Fama (1970) defines a market as efficient if prices fully reflect all available information and, therefore, stock prices are supposed to follow a "random walk". The EMH comes in three forms: the weak form states that current prices fully incorporate information contained in the past history of prices only; the semi-strong form of the EMH states that current prices fully incorporate all publicly available information, which includes past prices but also other forms of possibly relevant information on fundamental or macroeconomic factors; and the strong form states that current prices incorporate all existing public and private information. The latter implies that it is not possible to generate profits in trading even when using non-public information (Clarke et al. 2001). The EMH excludes the possibility of having a speculative component in stock prices and argues that prices in efficient markets are unforecastable (Samuelson, 1965), since the only variable to determine stock prices is information. In other words, it is not possible to outperform the markets on a regular basis. The EMH reached its peak of popularity in the 1970s.

In discounted cash flows (DCF) models, the price of a stock reflects all the future profits derived from that stock, discounted to the present day using a given discount rate. The discount rate usually has two components: a risk-free part and a risk premium. Fischer (1930) and Burr Williams (1938) described the main arguments of this method, which was fairly popular after the Great Depression in

Unless, of course, there is a capital increase or a similar operation. 
1929. When the DCF is applied to the price of stocks in efficient markets, their price should reflect their intrinsic long-term value, which is given by the present value of its future net cash flows, including dividend distributions and the selling price. However, the DCF is subject to substantial assumption bias and minor changes in the assumptions (for example, the discount rate or the future dividends) may fundamentally change the final result (Damodaran, 2011; Steiger, 2008).

Behavioural finance, which emerged in the 1990 s, focuses on modelling human psychology in its relation to financial markets, shifting away from econometric analyses of prices, future cash flows and similar variables. Byrne and Brooks (2008) comprehensively review the many avenues of behavioural finance. One first area of work discusses whether and how investor sentiment can affect stock prices and returns. Traditional finance has typically given little attention to investment sentiment in asset pricing but several researchers have found evidence of investor sentiment affecting stock returns, in particular those which are more difficult to value (Baker and Wurgler, 2006; Tetlock, 2007). Actually, Baker and Wurgler (2007) find that stock prices of low capitalised, younger, unprofitable, highly volatile, non-dividend paying, intensively growing or distressed companies are more likely to be affected by broad waves of investor sentiment. A second relevant area of work in behavioural finance refers to the under- and overreaction of investors to information in prices of securities. Empirical evidence suggests that stock prices show short-term (up to 12 months) return continuations, also called momentum, while this trend is reversed in the longer term (Jegadeesh and Titman, 1993). Moreover, behavioural finance claims that it can explain why and how financial markets are inefficient. Even if Fama (1998) considers that markets can generally be considered efficient, behavioural economists believe that psychological factors in investors may drive prices far from their fundamental value (De Bondt et al., 2015; Schiller, 2003; Shleifer, 2000).

Behavioural finance introduces the concept of investor sentiment, which Baker and Wurgler (2007) define as a belief about future cash flows and investment risks that is not justified by the facts at hand, as one of the main factors to explain movements in stock prices. The notion of investor sentiment is close to the analysis done in this paper, which tries to determine those bankspecific variables which may be driving the demand of stocks of European banks and whether these variables can change over short periods of time. Even if at a rather modest level, this paper can contribute to this stream of academic literature.

In the search of these bank-specific variables, the future evolution of profits and dividends, as outlined by the DCF models, emerges as a significant factor to drive stock prices and returns. A second set of relevant variables are those related to asset quality. At this point, it is also necessary to refer to the probability of default of an entity, as it is directly linked with the asset quality of a bank as well as with the behaviour of investors. A key contribution in this area is that of Merton (1974), who develops a model for the pricing of bonds, according to which, the probability of default of an entity would be a non-linear function of leverage, volatility and risk-free rates. In this sense, investors in equity markets would demand certain compensation for investing in banks, which are sensitive to tail risk events. So, considering similar leverage and exogenous riskfree rates, those banks which are more affected by periods of financial turmoil (higher volatility of stock prices) would have a higher probability of default. Nagel and Purnanandam (2015) amend the Merton model as they consider that volatility of assets is not constant, as assumed by Merton, but can rise substantially following a bad asset value shock. In this sense, they highlight the importance of asset quality in the determination of the probability of default of a bank.

\subsection{Determinants of bank stock prices and returns}

The main contribution of this paper relates to the stream in the literature exploring the determinants of bank stock prices and returns. Hence, the following paragraphs discuss relevant papers from the academic literature in this field. 
There are numerous academic papers which look at the determinants of bank stock prices and returns from a structural point of view, covering a long period of time and using a limited set of independent variables. To name just few of the many studies available, Liadakia and Gaganis (2010) find evidence that changes in efficiency have a positive and significant impact on stocks prices. Demirgüç-Kunta and Huizinga (2013) investigate the impact of bank size and government deficits on bank stock prices and CDS spreads and find that a bank market-to-book value is negatively related to the size of its liabilities-to-GDP ratio. Castrén et al. (2006) combine the dynamic dividend-discount model with an accounting-based vector autoregression framework that allows for a decomposition of EU banks stock returns to cash-flow and expected return news components. They find that a significant part of the changes in EU banks stock returns can be explained by cash-flows, with higher importance of this factor in the case of large banks. They also find evidence suggesting that large banks could be more sensitive to market-wide news and events, as opposed to bank-specific news. Cooper at al. (2003) use bank-specific variables over a sample of US banks to check which ones determine their stock returns and find that variables related to non-interest income, impairment allowances (loan-loss reserves), earnings, leverage, and standby letters of credit are relevant to forecast bank stock returns. Surprisingly, book-tomarket ratios and size are not relevant in their sample.

As said, these papers take a structural approach, as they look at the evolution of bank stock prices and returns over a long horizon. From a conjectural perspective, several authors have recently looked at variables which could explain stock performance of banks during the global financial crisis.

Beltratti and Stulz (2012) find that banks with larger funding from short-term capital markets saw their stock prices decline more than others during 2007 and 2008. Other factors, like regulation or corporate governance did not seem to be a relevant factor in the evolution of stock prices in those years. Interestingly, they do not include variables related to asset quality in their regressions. It is also worth referring to Fahlenbrach et al. (2012), who compare stock performance of US banks during the 1998 financial crisis and the global financial crisis. They find that, for each percentage point of loss in the value of its equity in 1998, a bank lost an annualized 66 basis points during the global financial crisis. These findings are consistent with the risk culture hypothesis and inconsistent with the learning hypothesis; in other words, according to the authors, there seem to be some banks which tend to continuously take on more risk and are always hit by crisis, not learning from the past experiences. Aebi et al. (2012) investigate the relation between bank stock returns during 2007 and 2008 and the governance structure of a sample of US banks. While standard governance measures do not seem to be significant factors explaining the performance of US banks during the crisis, variables related to risk governance are. Finally, Salvador (2017) compares the reaction of banks stock returns to actions by credit rating agencies before and after the global financial crisis. He finds a change in the reaction of investors to changes in the ratings of a sample of European banks after the crisis, when they become more sensitive to upgrades. He also documents different reactions to changes in ratings by different agencies.

In what concerns bank-specific variables, Filbeck et al. (2011) argue that size positively impacted stock performance of US banks before the global financial crisis, as it would provide additional resilience to changing economic conditions. Irresberger et al. (2015) examine the role of investors' sentiment indicators in the performance of the stock prices of sample of more than 400 banks, during the global financial crisis. They find that idiosyncratic bank variables as well as investors' market sentiment influenced the price dynamics of banks those years, with healthier and larger banks being less influenced by market sentiment. In this area, it is also interesting to note the findings of Cabrera et al. (2016), who argue that bank stock returns fall in response to a deterioration of governments' financial situation. When they add bank-specific variables, only the return of assets is statistically significant in their regressions, while they have little evidence on the significance of the size of banks. 
Considering the determinants of bank stock returns, the model by Yang and Tsatsaronis (2012) explains bank stock returns using three factors: differences with the broader market returns, size and value. The model is further expanded with the addition of leverage, earnings, book-tomarket values and the business cycle. They find that the excess returns on bank equities are highly correlated with the business cycle (measured as deviations from GDP trends), with a relevant role played in the majority of specifications by market returns, leverage, size and earnings. In a similar vein, Chan-Lau et al. (2012) use fixed-effect panel regressions to assess the impact of growth, sovereign risk, funding stress and investor sentiment on banks' equity returns. They find that sovereign risk, purchasers' managers indexes and the VIX are relevant to explain the evolution of bank stock returns between January 2006 and October 2011. When their specification is expanded to incorporate bank-specific variables for a sample of euro area banks, they find that only leverage is statistically significant. In general terms, Chan-Lau et al. (2012) find that better capitalised banks and those with less leverage performed better during the crisis.

This paper is also indirectly related to the literature on event studies on equity performance. In this domain, Schweitzer (1989) provides an accessible and interesting introduction to the field of event studies. In relation to event studies focused on bank stock returns, it is worth referring shortly to Cao and Petrasek (2014), who analyse the factors which affect the relative performance of stocks during liquidity crises and find that abnormal stock returns during liquidity crises are strongly negatively related to liquidity risk; and to Schäfer et al. (2013), who analyse the reaction of stock returns and CDS spreads of banks from Europe and the United States to four major regulatory reforms in the aftermath of the global financial crisis and find evidence of a market reaction to the introduction of these pieces of regulation.

To sum up, this paper aims at explaining why the stock returns of a given bank fell more sharply than those of another bank in three concrete episodes of market turmoil, having, thus, a strong cross-sectional component. Therefore, bank-specific variables are of the essence, bringing the paper under the stream of literature working on determinants of bank stock returns. At the same time, as the focus is on three periods of financial turmoil, the paper also relates to the literature on event studies. Lastly, the paper tries to identify whether there has been changes in the factors driving investors demand for bank stocks, a task related to the literature on the determinants of stock prices and of investor demand over short periods of time.

\section{METHODOLOGY AND DATA}

\subsection{Methodology}

This paper purposely remains simple in the approach and does not try to define a new theoretical model to explain valuation of bank stocks. On the contrary, it takes a fully empirical approach by using publicly available bank-level information to try to explain the dynamic behaviour of stock returns in three concrete periods of financial turmoil. The choice for stock returns and not for stock prices is made in order to consider dividends and other benefits paid to shareholders.

In what regards the periods of financial turmoil, they refer to declines in stock returns observed within a month or two, occurring all of them after the global financial crisis. The first period happened in August 2015 and for the purposes of this paper it is assumed to coincide with the calendar month of August. It has been chosen because it extended to the majority of listed institutions, not particularly affecting banks. The second period covers the last days of 2015 and the first days of 2016. For the purposes of the regressions, it is expected to start on 1 December 2015 and to finish on 31 January 2016. In this case, contrary to the previous period, concerns of market participants focused mostly on EU banks, with other stocks showing a less negative evolution. Finally, we have selected as our third period the last week of June 2016, following the 
outcome of the UK vote regarding its EU membership. Even if not completely accurate but to ensure a coverage of at least one month, this period is assumed to start on 1 June 2016 and finish on 30 June 2016. Interestingly, stock returns declines in this period did not seem to be directly related with the UK, but were seen mainly as a continuation of the stock return declines in the second period.

The initial equation which we try to regress on each period $t$ is as follows:

$$
\mathrm{R}_{\mathrm{t}}-\mathrm{R}_{\mathrm{t}-1}=\Delta \mathrm{R}=\mathrm{a}_{\mathrm{t}}+\beta_{1} \mathrm{~S}_{\mathrm{t}}+\beta_{2} \mathrm{P}_{\mathrm{t}}+\beta_{3} \mathrm{AQ}_{\mathrm{t}}+\varepsilon_{\mathrm{t}}
$$

where $\mathrm{R}$ is the monthly return of the stock, a is a constant, $\mathrm{S}$ refers to an indicator on the size of the bank, $\mathrm{P}$ is an indicator related to the profitability of the bank, AQ is an indicator referring to the asset quality, $\varepsilon$ is the error term and $\beta_{1}, \beta_{2}$ and $\beta_{3}$ refer to the coefficients of each indicator.

The three categories of indicators (size, profitability and asset quality) have been chosen as they are typically identified as relevant, on a bank-specific basis, for the performance of bank stocks. In addition to factors like economies of scale and diversification, size could also be related to the existence of an implicit subsidy in financial markets for larger institutions, for reasons of their too-big-to-fail status. Profitability directly relates to the capability of a bank to generate returns, normally in the form of dividends, for its shareholders on a sustainable basis. Finally, asset quality variables are closely related to the macroeconomic environment of the bank and may reflect the impact of that environment on the normal course of business of banks and on its probability of default.

Instead of considering a close set of indicators, which would entail the difficult and subjective decision of choosing the most informative one, several indicators for each of the three characteristics under consideration have been considered. This would add some robustness to the results in case indicators of similar nature behave similarly in the regression.

The indicators we have considered are summarised in Table 1.

Table 1.

Indicators considered in the regressions

\begin{tabular}{llll}
\hline \hline \multirow{2}{*}{ Size } & Total assets & $\begin{array}{l}\text { logs, thousands } \\
\text { of Euros }\end{array}$ & Total assets according to accounting standards \\
\cline { 2 - 4 } & Total capital & $\begin{array}{l}\text { logs, thousands } \\
\text { of Euros }\end{array}$ & Total capital according to accounting standards \\
\cline { 2 - 4 } & Domestic exposures & percentage & $\begin{array}{l}\text { Percentage of banking book exposures located in the } \\
\text { domestic country of the bank }\end{array}$ \\
\cline { 2 - 4 } Profitability & Return on equity & percentage & Ratio between net profit and equity of the bank \\
\cline { 2 - 4 } & Net interest margin & percentage & $\begin{array}{l}\text { Net interest income (interest income minus interest } \\
\text { expense) to total assets }\end{array}$ \\
\hline \multirow{2}{*}{ Asset quality } & Texas ratio & percentage & $\begin{array}{l}\text { Gross carrying amount of non-performing loans divided } \\
\text { by the sum of own funds and accumulated provisions }\end{array}$ \\
\cline { 2 - 4 } & NPL rate & percentage & $\begin{array}{l}\text { Gross non-performing loans to total gross loans, for } \\
\text { loans to households and non-financial corporations }\end{array}$ \\
\hline \hline
\end{tabular}

Source: Author's elaboration.

The seven indicators in Table 1, which would enter the regression in equation (1) as independent variables, have been selected on the basis of the following considerations:

- The three indicators related to size would cover the size of the balance sheet of the bank (total assets) as well as the capital available for the bank to withstand unexpected losses (total 
capital). In both cases, amounts are taken from the accounting domain. The third variable (domestic exposures) tries to capture the cross-border dimension of each bank, in the sense that highly interconnected banks could enjoy a certain too-big-to-fail status in comparison with entities of similar size and risk profile.

- For profitability, net interest margin would consider the ability of banks to generate profits in their core business (granting loans and accepting deposits from customers). Return on equity would put the profit generated by the bank in the broader context of the remuneration of the shareholder and of the difference with the cost of capital. In the first case, higher remunerations to shareholders would, in principle, lead to increases in stock returns, while, in the second case, positive differences with the cost of capital would point towards a sustainable path of profits into the future.

- Regarding asset quality, the NPL rate is the most common and basic indicator for comparing asset quality across banks. This indicator is complemented by the Texas ratio, which measures the portion of NPLs which are not covered by either capital or accumulated provisions. Historically, the Texas ratio has performed rather well as an indicator of banks under stress.

A basic OLS regression is run first over the cross-sectional data for a sample of 53 EU banks. ${ }^{3}$ Each of the three episodes of financial turmoil is considered separately, allowing us to better understand the dynamics of market participants towards EU banks in each particular episode. In other words, three sets of regressions are run. In terms of the indicators in Table 1, all possible combinations of the variables in Table 1 are covered, leading to a total of 12 regressions. ${ }^{4}$ Then, those variables which are statistically significant (according to their p-values) ${ }^{5}$ and which have the expected sign are considered to be relevant in the explanation of the change in the stock returns of banks. Additionally, measures of goodness of fit (adjusted R squared, SE of regression, log likehood, Akaike info criterion, Schwarz criterion and Hannan-Quinn criterion) are also assessed, as they could hint at the regressions and variables with the highest explanatory power.

This is somehow a novel approach, as it relies entirely on bank-specific indicators to explain the evolution of stock returns and it gives the same consideration to all banks in the sample, regardless of their country of domicile. On the first point, it is important to note that the macroeconomic environment of each bank is indirectly present in the regressions, via the variables related to asset quality and, to a lesser extent, to profitability (there is prolific literature on the link between the macroeconomic environment and NPLs; see, for example, Beck et al., 2013). Besides, the purpose of the paper is not placed on the relation between stock returns and the macroeconomic environment, but to identify factors which investors weigh when in a period of financial stress. The main reason for non-discriminating by country is that in the three episodes it has been observed that stock returns of banks with domicile in the same country evolved differently. At the same time, introducing a series of country dummies would negative affect the degrees of freedom of the OLS regression, which are already rather constrained.

Nonetheless, for robustness purposes, a second set of regressions are run, considering only one regression per period. These regressions would, first, start with all the indicators outlined in Table 1, complemented with control variables for the macroeconomic environment, the stock market performance (index returns) and the country of the bank will be added to the regression. So, in a stylised way, equation (1) would then become:

$$
\mathrm{R}_{\mathrm{t}}-\mathrm{R}_{\mathrm{t}-1}=\Delta \mathrm{R}=\beta_{1} \mathrm{~S}_{\mathrm{t}}+\beta_{2} \mathrm{P}_{\mathrm{t}}+\beta_{3} \mathrm{AQ}_{\mathrm{t}}+\beta_{4} \mathrm{ME}_{\mathrm{t}}+\beta_{5} \mathrm{SI}_{\mathrm{t}}+\beta_{6} \mathrm{C}_{\mathrm{t}}+\varepsilon_{\mathrm{t}}
$$

Tests for spatial auto-correlation and for heteroscedasticity (White's) are run over each regression.

These are the following: (1) total assets, net interest margin, NPL rate; (2) total assets, net interest margin, Texas ratio; (3) total assets, ROE, NPL rate; (4) total assets, ROE, Texas ratio; (5) total capital, net interest margin, NPL rate; (6) total capital, net interest margin, Texas ratio; (7) total capital, ROE, NPL rate; (8) total capital, ROE, Texas ratio; (9) domestic exposures, net interest margin, NPL rate; (10) domestic exposures, net interest margin, Texas ratio; (11) domestic exposures, ROE, NPL rate; and (12) domestic exposures, ROE, Texas ratio.

For a significance level of 0.05 . 
where, in addition to the variables in equation (1), ME refers to a variable capturing the macroeconomic environment, $\mathrm{I}$ is a stock market return index, $\mathrm{C}$ is a dummy variable referring to the country of domicile of each bank, and $\beta_{4}, \beta_{5}$ and $\beta_{6}$ refer to the coefficients of each indicator. The constant is dropped from this equation as it would generate collinearity with the control variables introduced.

\subsection{Data}

The change in stock returns is calculated as the difference between the return of a given stock at the end of the month and the return of the same stock at the beginning of the month. For the second period December 2015-January 2016, the two months are considered together. The descriptive statistics of the change in stock returns of the EU banks in the sample are provided in Table 2, while Figure 2 shows the distribution of banks in the three periods according to the changes in their stock returns. In the three periods under consideration, the stock returns at the end of the period were lower than at the beginning for approximately $90 \%$ of the 53 banks in the sample. It is worth noting that the change in stock returns in the month of August 2015 was the smallest, on average, while the decreases in stock returns in the other two periods are of a similar magnitude. The amplitude of the change in stock returns (given by the difference between maximum and minimum) are lower for the period of August 2015 and substantially higher for the other two periods, in particular for the period December 2015-January 2016.

Table 2.

Descriptive statistics of changes in stock returns

\begin{tabular}{lccc}
\hline \hline & August 2015 & December 2015-January 2016 & June 2016 \\
\hline Mean & $-5.62 \%$ & $-17.65 \%$ & $-16.78 \%$ \\
Median & $-5.24 \%$ & $-14.31 \%$ & $-18.01 \%$ \\
Minimum & $-17.60 \%$ & $-78.18 \%$ & $-40.53 \%$ \\
Maximum & $3.98 \%$ & $4.63 \%$ & $4.68 \%$ \\
Standard deviation & $4.66 \%$ & $16.27 \%$ & $11.64 \%$ \\
\% of stocks with a negative variation & $88.24 \%$ & $92.16 \%$ & $92.16 \%$ \\
\hline
\end{tabular}

Number of banks in each interval of changes in stock returns

\begin{tabular}{lrcc}
\hline$>0.05$ & 0 & 0 & 0 \\
{$[0 / 0.05)$} & 8 & 6 & 6 \\
{$[-0.05 / 0)$} & 16 & 3 & 5 \\
{$[-0.10 /-0.05)$} & 20 & 11 & 7 \\
{$[-0.15 /-0.10)$} & 7 & 7 & 4 \\
{$[-0.20 /-0.15)$} & 2 & 7 & 8 \\
{$[-0.25 /-0.20)$} & 0 & 7 & 11 \\
{$[-0.30 /-0.25)$} & 0 & 5 & 4 \\
{$[-0.35 /-0.30)$} & 0 & 2 & 4 \\
$<-0.35$ & 0 & 5 & 4 \\
\hline \hline
\end{tabular}

Source: Bloomberg and author's calculation. 
Figure 2 also visually shows how changes in stock returns over the three periods were differently distributed. Changes in stock returns in August 2015 were highly concentrated around the mean, while, for the other two periods, larger heterogeneity is observed. The bank-specific factors behind this heterogeneity in the changes in stock returns constitute the core of the analysis in this paper.

Figure 2.

Distribution of changes in bank stock returns (number of banks in each interval)

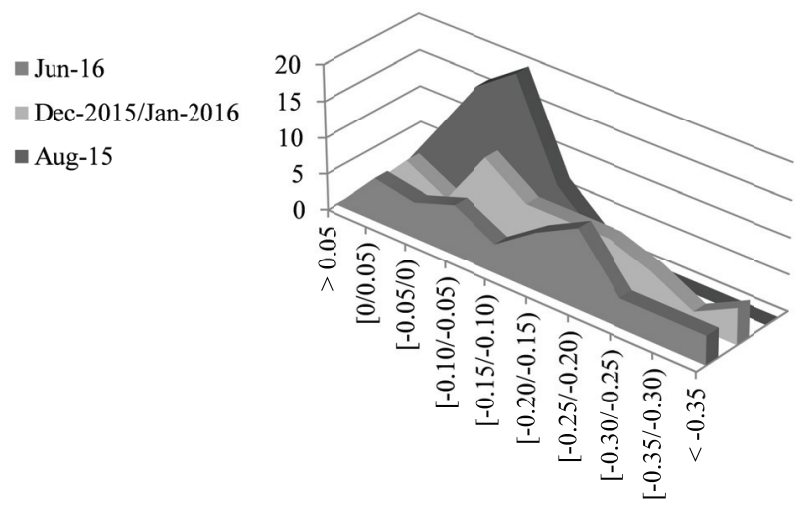

Source: Bloomberg and author's calculations.

The dataset used for the independent variables in equation (1) is mostly derived from the European Banking Authority (EBA) Transparency Exercises of years 2015 and 2016. It covers an initial sample of 53 large EU banking groups, which are also listed in equity markets. Two banks were removed from the data in the two most recent periods due to significant restructuration. The initial sample of 53 banks comprises 10 Italian banks, 9 Spanish, 4 German, 4 Swedish, 4 British, 3 Danish, 3 Dutch, 3 Irish, 2 Cypriote, 2 French, 2 Portuguese, 1 Austrian, 1 Belgian, 1 Polish, 1 Norwegian 1 Maltese, 1 Hungarian and 1 Slovenian.

The data used in the regressions for the decline in stock returns in August 2015 has a reference date of 30 June 2015. In the case of December 2015 and January 2016, and June 2016, data with reference dates 31 December 2015 and 30 June 2016 have been used, respectively. The only exception to that is the data for the percentage of domestic exposures, which is computed with a reference date of 30 June 2015 for the three cases, due to the limited availability of the necessary data to calculate them in the most recent EBA Transparency Exercise. Given the structural nature of the underlying information (the cross-border activity of a given bank), no major impact should be expected from this exception. Besides, in limited cases, data on total assets and total capital had to be proxied using leverage ratio exposures from the EBA Transparency Exercise 2015 or, in only one case, using the same data than in the previous period.

Leaving aside these exceptions, the choice of reference dates tries to ensure that the most recent data to each episode is used, even if it was not publicly available. The reasoning behind this decision is that it is assumed that stock prices and returns, as well as market participants, almost contemporaneously absorb all information from the underlying banks (more inclined, then, towards a strong EMH).

As the variable to control for the macroeconomic environment, the closest available quarterly growth rate of GDP of the country of domicile of the bank is selected. The Eurostoxx 50 stock returns (already shown in Figure 1) would be the control variable for the evolution of stock markets. Finally, for the country of domicile of the bank a dummy variable is introduced, which takes the value of 1 for those banks domiciled in an EU country which was more severely hit by the global financial crisis (Hungary, Ireland, Cyprus, Portugal, Slovenia, Spain and Italy). These are countries where there has been a form of financial assistance since 2008 or where the 
banking system has been confronted with a significant peak in the levels of NPLs and widespread concerns about their banking system.

For each bank and for each reporting date, data as described in Table 3 is used in the different regressions.

Table 3.

Information on data used in the regressions

\begin{tabular}{|c|c|c|}
\hline Indicator & Source & Reference dates \\
\hline $\begin{array}{l}\text { Stock returns } \\
\text { (EuroStoxx } 50 \text { and banks) }\end{array}$ & Bloomberg & $\begin{array}{l}\text { Changes in monthly returns } \\
\text { in August 2015, December } \\
\text { and January 2015, and June } 2016\end{array}$ \\
\hline Total assets & $\begin{array}{l}\text { SNL (if not available, leverage ratio exposures, } \\
\text { banks' financial statements or data from } \\
\text { previous periods) }\end{array}$ & $\begin{array}{l}30 \text { June } 2015,31 \text { December } 2015 \\
\text { and } 30 \text { June } 2016\end{array}$ \\
\hline Total capital & $\begin{array}{l}\text { SNL (if not available, leverage ratio exposures, } \\
\text { banks' financial statements or data from } \\
\text { previous periods) }\end{array}$ & $\begin{array}{l}30 \text { June } 2015,31 \text { December } 2015 \\
\text { and } 30 \text { June } 2016\end{array}$ \\
\hline Domestic exposures & $\begin{array}{l}\text { EBA Transparency Exercises } 2015 \text { and } 2016 \text {, } \\
\text { and author's calculations }\end{array}$ & 30 June 2015 \\
\hline Return on Equity & $\begin{array}{l}\text { EBA Transparency Exercises } 2015 \text { and 2016, } \\
\text { and author's calculations }\end{array}$ & $\begin{array}{l}30 \text { June } 2015,31 \text { December } 2015 \\
\text { and } 30 \text { June } 2016\end{array}$ \\
\hline Net interest margin & $\begin{array}{l}\text { EBA Transparency Exercises } 2015 \text { and 2016, } \\
\text { and author's calculations }\end{array}$ & $\begin{array}{l}30 \text { June } 2015,31 \text { December } 2015 \\
\text { and } 30 \text { June } 2016\end{array}$ \\
\hline Texas ratio & $\begin{array}{l}\text { EBA Transparency Exercises } 2015 \text { and } 2016 \text {, } \\
\text { and author's calculations }\end{array}$ & $\begin{array}{l}30 \text { June } 2015,31 \text { December } 2015 \\
\text { and } 30 \text { June } 2016\end{array}$ \\
\hline NPL rate & $\begin{array}{l}\text { EBA Transparency Exercises } 2015 \text { and } 2016 \text {, } \\
\text { and author's calculations }\end{array}$ & $\begin{array}{l}30 \text { June } 2015,31 \text { December } 2015 \\
\text { and } 30 \text { June } 2016\end{array}$ \\
\hline $\begin{array}{l}\text { Quarterly growth rate } \\
\text { of GDP }\end{array}$ & Eurostat & $\begin{array}{l}30 \text { September } 2015,31 \text { December } \\
2015 \text { and } 30 \text { June } 2016\end{array}$ \\
\hline
\end{tabular}

Source: Author's elaboration.

Descriptive statistics of the bank-specific independent variables are provided in Table 4. Since the reference dates for the data used in the regressions for the three periods span over a relatively short period of time (one year, from June 2015 to June 2016), there are no major developments observable in the data. It is worth noting, though, a rather limited improvement in the variables of a more cyclical nature (return on equity and NPL rate). 
Table 4.

Descriptive statistics of bank-specific independent variables

\begin{tabular}{|c|c|c|c|c|c|}
\hline \multicolumn{6}{|c|}{ August 2015 (reference date 30 June 2015) } \\
\hline & & Mean & Median & Minimum & Maximum \\
\hline Total assets & thousand $€$ & $412,869,732$ & $129,800,000$ & $4,650,000$ & $2,176,062,228$ \\
\hline Total capital & thousand $€$ & $23,116,389$ & $9,443,500$ & 552,000 & $157,193,067$ \\
\hline Domestic exposures & $\%$ & $70.82 \%$ & $77.43 \%$ & $1.23 \%$ & $100.00 \%$ \\
\hline Return on Equity & $\%$ & $2.53 \%$ & $4.52 \%$ & $-61.65 \%$ & $9.42 \%$ \\
\hline Net interest margin & $\%$ & $1.35 \%$ & $1.27 \%$ & $0.35 \%$ & $4.01 \%$ \\
\hline Texas ratio & $\%$ & $72.36 \%$ & $57.10 \%$ & $8.27 \%$ & $204.65 \%$ \\
\hline NPL rate & $\%$ & $13.87 \%$ & $9.62 \%$ & $0.63 \%$ & $60.67 \%$ \\
\hline
\end{tabular}

December 2015 - January 2016 (reference date 31 December 2015)

\begin{tabular}{llcccc}
\hline & & Mean & Median & Minimum & Maximum \\
Total assets & thousand $€$ & $411,717,916$ & $144,804,937$ & $4,246,167$ & $2,218,570,279$ \\
Total capital & thousand $€$ & $25,164,608$ & $10,070,235$ & 623,073 & $181,854,823$ \\
Domestic exposures & $\%$ & $70.82 \%$ & $77.43 \%$ & $1.23 \%$ & $100.00 \%$ \\
Return on Equity & $\%$ & $5.15 \%$ & $6.08 \%$ & $-18.26 \%$ & $14.65 \%$ \\
Net interest margin & $\%$ & $1.47 \%$ & $1.35 \%$ & $0.11 \%$ & $5.10 \%$ \\
Texas ratio & $\%$ & $63.42 \%$ & $47.51 \%$ & $6.75 \%$ & $186.79 \%$ \\
NPL rate & $\%$ & $13.29 \%$ & $7.82 \%$ & $0.60 \%$ & $60.57 \%$ \\
\hline
\end{tabular}

June 2016 (reference date 30 June 2016)

\begin{tabular}{llcccc}
\hline & & Mean & Median & Minimum & Maximum \\
\hline Total assets & thousand $€$ & $425,952,129$ & $144,747,352$ & $4,224,392$ & $2,349,942,249$ \\
Total capital & thousand $€$ & $24,671,583$ & $9,636,282$ & 633,489 & $178,665,597$ \\
Domestic exposures & $\%$ & $70.82 \%$ & $77.43 \%$ & $1.23 \%$ & $100.00 \%$ \\
Return on Equity & $\%$ & $6.72 \%$ & $7.47 \%$ & $-18.33 \%$ & $21.11 \%$ \\
Net interest margin & $\%$ & $1.48 \%$ & $1.36 \%$ & $0.10 \%$ & $4.81 \%$ \\
Texas ratio & $\%$ & $61.21 \%$ & $46.40 \%$ & $7.05 \%$ & $178.12 \%$ \\
NPL rate & $\%$ & $12.77 \%$ & $7.15 \%$ & $0.52 \%$ & $57.82 \%$ \\
\hline \hline
\end{tabular}

Source: EBA, SNL and author's calculation.

As explained above, together with the regressions using solely bank-specific variables, a second set of regressions is run, where variables are added to control for the macroeconomic environment: quarterly rate of growth of GDP at current prices of the country of domicile of the bank (measured in national currency, seasonally and calendar adjusted); the evolution of the general stock market index (change in monthly returns of the EuroStoxx50); and the country of domicile of the bank (dummy variable). Descriptive statistics for the first two variables are provided in Table 5 below. 
Table 5.

Descriptive statistics of independent variables used as controls

\begin{tabular}{lccccc}
\hline \hline & & Quarterly growth rate of GDP & $\begin{array}{c}\text { EuroStoxx 50 monthly } \\
\text { stock return - change }\end{array}$ \\
& Mean & Median & Minimum & Maximum & Value \\
\hline August 2015 & $0.99 \%$ & $0.74 \%$ & $-0.06 \%$ & $4.87 \%$ & $-8.31 \%$ \\
December 2015-January 2016 & $0.80 \%$ & $0.87 \%$ & $-0.19 \%$ & $2.40 \%$ & $-9.88 \%$ \\
June 2016 & $0.66 \%$ & $0.68 \%$ & $-0.27 \%$ & $2.27 \%$ & $-3.96 \%$ \\
\hline \hline
\end{tabular}

Source: Eurostat, Bloomberg and author's calculation.

A comparison of the evolution of the changes in the stock returns of the EuroStoxx50 (Table 5) and of the stock returns for our sample of banks (Table 2) reveals that the EuroStoxx 50 fell more than the banks in our sample in August 2015, with the opposite being observed in the other two periods, in particular for June 2016. Regarding the macroeconomic environment, it seems to be deteriorating as time went by.

Finally, Table 6 shows the correlations between all the variables considered in the two sets of regressions for each of the periods (with the exception of changes in EuroStoxx 50 returns). Correlations amidst independent variables will be used when running the second set of regressions (those with control variables) as guidance to gain degrees of freedom by reducing the number of independent variables. Highest correlations are found between the variables of total assets and total capital, followed by the NPL rate and the Texas ratio. In general, independent variables belonging to any of the three wide categories (size, profitability, asset quality) show significant correlations among them.

Table 6.

Correlation matrixes of independent variables

August 2015

\begin{tabular}{|c|c|c|c|c|c|c|c|c|c|}
\hline & $\begin{array}{c}\text { Total } \\
\text { assets }\end{array}$ & $\begin{array}{l}\text { Total } \\
\text { capital }\end{array}$ & $\begin{array}{l}\text { Domestic } \\
\text { exposures }\end{array}$ & $\begin{array}{l}\text { Return } \\
\text { on Equity }\end{array}$ & $\begin{array}{l}\text { Net interest } \\
\text { margin }\end{array}$ & $\begin{array}{l}\text { NPL } \\
\text { rate }\end{array}$ & $\begin{array}{l}\text { Texas } \\
\text { ratio }\end{array}$ & $\begin{array}{l}\text { GDP } \\
\text { growth }\end{array}$ & Country \\
\hline Total assets & 1.0000 & & & & & & & & \\
\hline Total capital & 0.9514 & 1.0000 & & & & & & & \\
\hline Domestic exposures & -0.5979 & -0.5657 & 1.0000 & & & & & & \\
\hline Return on Equity & 0.1127 & 0.1216 & -0.1742 & 1.0000 & & & & & \\
\hline Net interest margin & -0.1911 & -0.1346 & -0.2472 & -0.0434 & 1.0000 & & & & \\
\hline NPL rate & -0.3669 & -0.3354 & 0.4018 & -0.0345 & 0.1501 & 1.0000 & & & \\
\hline Texas ratio & -0.4512 & -0.4173 & 0.5203 & -0.2054 & 0.0558 & 0.8644 & 1.0000 & & \\
\hline GDP growth & -0.2568 & -0.2518 & -0.0147 & -0.0477 & 0.0994 & 0.1269 & 0.1991 & 1.0000 & \\
\hline Country & -0.4056 & -0.3194 & 0.4473 & 0.0419 & 0.1219 & 0.6385 & 0.7170 & 0.2617 & 1.0000 \\
\hline
\end{tabular}


December 2015-January 2016

\begin{tabular}{|c|c|c|c|c|c|c|c|c|c|}
\hline & $\begin{array}{c}\text { Total } \\
\text { assets }\end{array}$ & $\begin{array}{c}\text { Total } \\
\text { capital }\end{array}$ & $\begin{array}{l}\text { Domestic } \\
\text { exposures }\end{array}$ & $\begin{array}{c}\text { Return } \\
\text { on Equity }\end{array}$ & $\begin{array}{c}\text { Net interest } \\
\text { margin }\end{array}$ & $\begin{array}{l}\text { NPL } \\
\text { rate }\end{array}$ & $\begin{array}{l}\text { Texas } \\
\text { ratio }\end{array}$ & $\begin{array}{l}\text { GDP } \\
\text { growth }\end{array}$ & Country \\
\hline Total assets & 1.0000 & & & & & & & & \\
\hline Total capital & 0.9589 & 1.0000 & & & & & & & \\
\hline Domestic exposures & -0.6284 & -0.5829 & 1.0000 & & & & & & \\
\hline Return on Equity & -0.0414 & -0.0023 & -0.0463 & 1.0000 & & & & & \\
\hline Net interest margin & -0.1654 & -0.0838 & 0.0478 & -0.0760 & 1.0000 & & & & \\
\hline NPL rate & -0.3813 & -0.3457 & 0.3797 & -0.5042 & 0.4224 & 1.0000 & & & \\
\hline Texas ratio & -0.4634 & -0.4253 & 0.5022 & -0.4857 & 0.3018 & 0.8640 & 1.0000 & & \\
\hline GDP growth & -0.2171 & -0.1994 & 0.0317 & 0.0267 & 0.1679 & 0.0730 & 0.0150 & 1.0000 & \\
\hline Country & -0.4101 & -0.3229 & 0.4343 & -0.2244 & 0.3133 & 0.6096 & 0.7214 & 0.1723 & 1.0000 \\
\hline \multicolumn{10}{|c|}{ June 2016} \\
\hline & $\begin{array}{c}\text { Total } \\
\text { assets }\end{array}$ & $\begin{array}{c}\text { Total } \\
\text { capital }\end{array}$ & $\begin{array}{l}\text { Domestic } \\
\text { exposures }\end{array}$ & $\begin{array}{l}\text { Return } \\
\text { on Equity }\end{array}$ & $\begin{array}{l}\text { Net interest } \\
\text { margin }\end{array}$ & $\begin{array}{l}\mathrm{NPL} \\
\text { rate }\end{array}$ & $\begin{array}{l}\text { Texas } \\
\text { ratio }\end{array}$ & $\begin{array}{l}\text { GDP } \\
\text { growth }\end{array}$ & Country \\
\hline Total assets & 1.0000 & & & & & & & & \\
\hline Total capital & 0.9523 & 1.0000 & & & & & & & \\
\hline Domestic exposures & -0.6244 & -0.5872 & 1.0000 & & & & & & \\
\hline Return on Equity & 0.0119 & 0.0245 & -0.1095 & 1.0000 & & & & & \\
\hline Net interest margin & -0.2729 & -0.1679 & 0.0835 & 0.3409 & 1.0000 & & & & \\
\hline NPL rate & -0.3715 & -0.3363 & 0.3791 & -0.3038 & 0.3656 & 1.0000 & & & \\
\hline Texas ratio & -0.4590 & -0.4188 & 0.4902 & -0.4326 & 0.2157 & 0.8702 & 1.0000 & & \\
\hline GDP growth & 0.0162 & 0.0596 & -0.1717 & 0.1189 & 0.1934 & 0.0742 & -0.1044 & 1.0000 & \\
\hline Country & -0.4100 & -0.3120 & 0.4343 & -0.2299 & 0.3392 & 0.6055 & 0.7254 & -0.1735 & 1.0000 \\
\hline
\end{tabular}

Source: Author's calculation.

\section{DISCUSSION OF RESULTS}

The results of the regressions run under equations (1) and (2) over the three periods of market turmoil are separately discussed in the following paragraphs, with more detailed information available in the Appendix.

\subsection{August 2015}

The decline in stock returns of EU banks in August 2015 has been typically attributed to concerns about certain emerging market economies, following a significant expansion of financial flows into these economies in previous years. Consequently, it could be expected that EU banks of larger size would have seen their stock returns decline more, as they would be supposed to have higher exposures to emerging economies. The sign of the relation between total assets or total capital, and the stock returns would be negative: more size would imply a lower stock return. For domestic exposures, the contrary would apply: a positive sign would be expected, indicating that stocks of those banks with more domestic activities (and less cross-border activities) would decline less. 
Table 7 below summarises the main outcome of the regressions carried out on the August 2015 stock returns.

Table 7.

Results of the regressions on changes in stock returns in August 2015 - bank specific variables

\begin{tabular}{ccccc}
\hline \hline Regression & Constant & Size & Profitability & Asset quality \\
\hline 1 & $(+)$ & $(-)$ Total assets & $(-)$ Net interest margin & NPL \\
2 & $(+)$ & $(-)$ Total assets & $(-)$ Net interest margin & Texas ratio \\
3 & & $(-)$ Total assets & ROE & NPL \\
4 & & $(-)$ Total assets & ROE & Texas ratio \\
5 & $(+)$ & $(-)$ Total capital & Net interest margin & NPL \\
6 & $(+)$ & $(-)$ Total capital & Net interest margin & Texas ratio \\
7 & & $(-)$ Total capital & ROE & NPL \\
8 & & $(-)$ Total capital & ROE & Texas ratio \\
9 & $(-)$ & $(+)$ Domestic exposures & Net interest margin & NPL \\
10 & $(+)$ & $(+)$ Domestic exposures & Net interest margin & Texas ratio \\
11 & $(+)$ & $(+)$ Domestic exposures & ROE & NPL \\
12 & $(-)$ & $(+)$ Domestic exposures & ROE & Texas ratio \\
\hline \hline
\end{tabular}

Notes: Those variables which are statistically significant at a level of 0.05 are shown in bold, together with their sign. The sign of the constant is shown only when statistically significant.

Source: Author's calculation.

From these results, it can be observed how the variable used to quantify banks size is consistently significant over the regressions, with the expected sign in all cases. Variables on asset quality are never significant, whereas net interest margin, reflecting bank profitability, is statistically significant only in two out of the twelve regressions (but with the contrary sign as expected). These results seem to validate the starting assumption that the declines in stock returns of EU banks observed in August 2015 stemmed from concerns about growth in emerging economies and affected larger banks.

In terms of measures of goodness of fit, all the considered measures perform similarly across the twelve regressions. If any, the adjusted $\mathrm{R}$ squared would point towards the fifth regression, where capital, net interest margin and the NPL rate are the variables considered, but only capital is statistically significant, as that with highest goodness of fit.

The regressions considering only bank-specific variables have shown that the changes in stock returns affected mostly banks of larger size and with more cross-border activities. It is interesting to compare these results with those stemming from the introduction of control variables (Table 8 ). The first point to note is that, in the first four columns in Table 8 (considering all bank-specific variables, all variables, and all variables except total assets or total capital), there is no variable which is statistically significant at the level of 0.05 . Only when both total assets and total capital are excluded from the equation (column 5), the changes in EuroStoxx50 return and domestic exposures become significant, with positive sign in both cases, implying a positive relation between the share of domestic exposures and the changes in stock return as well as a certain co-movement between stock returns of the EuroStoxx50 and of the banks in our sample. The regression in column 5 also reveals some counterintuitive signs in some of the other variables (even if they are not statistically significant): the negative sign of GDP growth, net interest margin and return on equity, and the positive sign of the NPL rate and the Texas ratio. The exclusion of the GDP growth from the regression (column 6) does not introduce any significant change 
in the results. A regression without the Texas ratio (column 7) leads to the significance of the country dummy and the NPL rate, in addition to the changes in EuroStoxx50 return and the domestic exposures. While the country dummy reflects the expected negative sign (implying that those banks from countries more affected by the global financial crisis performed worse), the positive sign of the NPL rate seems to be sending an opposing signal. Dropping the NPL rate from the regression (column 8 ) makes also the country dummy not statistically significant, while leaving the coefficients of the other two statistically significant independent variables rather unchanged. Measures of goodness-of-fit suggest that regressions of columns 6 and 7 have the highest explanatory power.

Table 8.

Results of the regressions on changes in stock returns in August 2015

\begin{tabular}{|c|c|c|c|c|c|c|c|c|}
\hline & (1) & (2) & (3) & (4) & (5) & (6) & (7) & (8) \\
\hline GDP growth & & $\begin{array}{r}-0.4188 \\
0.5767\end{array}$ & $\begin{array}{r}-0.4278 \\
0.5720\end{array}$ & $\begin{array}{r}-0.4312 \\
0.5694\end{array}$ & $\begin{array}{r}-0.2623 \\
0.5618\end{array}$ & & & \\
\hline EuroStoxx 50 return & & $\begin{array}{r}-0.2293 \\
2.0119\end{array}$ & $\begin{array}{r}-0.8936 \\
1.6178\end{array}$ & $\begin{array}{r}-0.6856 \\
1.3729\end{array}$ & $\begin{array}{l}\mathbf{1 . 1 6 5 2} \\
0.3108\end{array}$ & $\begin{array}{l}\mathbf{1 . 1 9 3 9} \\
0.3020\end{array}$ & $\begin{array}{l}1.1928 \\
0.2814\end{array}$ & $\begin{array}{l}1.2500 \\
0.2921\end{array}$ \\
\hline Country & & $\begin{array}{r}-0.0277 \\
0.0186\end{array}$ & $\begin{array}{r}-0.0306 \\
0.0178\end{array}$ & $\begin{array}{r}-0.0292 \\
0.0178\end{array}$ & $\begin{array}{r}-0.0329 \\
0.0178\end{array}$ & $\begin{array}{r}-0.0346 \\
0.0173\end{array}$ & $\begin{array}{r}-\mathbf{0 . 0 3 4 5} \\
0.0153\end{array}$ & $\begin{array}{r}-0.0164 \\
0.0136\end{array}$ \\
\hline Constant & $\begin{array}{r}-0.0308 \\
0.1648\end{array}$ & & & & & & & \\
\hline Total assets & $\begin{array}{l}0.0256 \\
0.0307\end{array}$ & $\begin{array}{l}0.0099 \\
0.0315\end{array}$ & $\begin{array}{r}-0.0076 \\
0.0058\end{array}$ & & & & & \\
\hline Total capital & $\begin{array}{r}-0.0331 \\
0.0304\end{array}$ & $\begin{array}{r}-0.0176 \\
0.0312\end{array}$ & & $\begin{array}{r}-0.0080 \\
0.0058\end{array}$ & & & & \\
\hline Domestic exposures & $\begin{array}{l}0.0516 \\
0.0333\end{array}$ & $\begin{array}{l}0.0507 \\
0.0342\end{array}$ & $\begin{array}{l}0.0452 \\
0.0325\end{array}$ & $\begin{array}{l}0.0465 \\
0.0311\end{array}$ & $\begin{array}{l}\mathbf{0 . 0 7 1 1} \\
0.0259\end{array}$ & $\begin{array}{l}\mathbf{0 . 0 7 3 1} \\
0.0253\end{array}$ & $\begin{array}{l}\mathbf{0 . 0 7 3 1} \\
0.0246\end{array}$ & $\begin{array}{l}0.0845 \\
0.0252\end{array}$ \\
\hline Net interest margin & $\begin{array}{r}-0.7701 \\
1.2715\end{array}$ & $\begin{array}{r}-0.7524 \\
1.2575\end{array}$ & $\begin{array}{r}-1.0915 \\
1.0956\end{array}$ & $\begin{array}{r}-0.9638 \\
1.0499\end{array}$ & $\begin{array}{r}-0.5130 \\
1.0081\end{array}$ & $\begin{array}{r}-0.5267 \\
0.9991\end{array}$ & $\begin{array}{r}-0.5282 \\
0.9781\end{array}$ & $\begin{array}{r}-0.1741 \\
1.0065\end{array}$ \\
\hline Return on Equity & $\begin{array}{r}-0.0473 \\
0.0686\end{array}$ & $\begin{array}{r}-0.0265 \\
0.0691\end{array}$ & $\begin{array}{r}-0.0376 \\
0.0656\end{array}$ & $\begin{array}{r}-0.0324 \\
0.0657\end{array}$ & $\begin{array}{r}-0.0400 \\
0.0661\end{array}$ & $\begin{array}{r}-0.0387 \\
0.0655\end{array}$ & $\begin{array}{r}-0.0389 \\
0.0592\end{array}$ & $\begin{array}{r}-0.0421 \\
0.0617\end{array}$ \\
\hline NPL rate & $\begin{array}{l}0.1479 \\
0.1060\end{array}$ & $\begin{array}{l}0.1068 \\
0.1074\end{array}$ & $\begin{array}{l}0.0804 \\
0.0959\end{array}$ & $\begin{array}{l}0.0905 \\
0.0930\end{array}$ & $\begin{array}{l}0.1209 \\
0.0913\end{array}$ & $\begin{array}{l}0.1257 \\
0.0900\end{array}$ & $\begin{array}{l}\mathbf{0 . 1 2 6 4} \\
0.0557\end{array}$ & \\
\hline Texas ratio & $\begin{array}{r}-0.0292 \\
0.0297\end{array}$ & $\begin{array}{l}0.0016 \\
0.0339\end{array}$ & $\begin{array}{l}0.0076 \\
0.0320\end{array}$ & $\begin{array}{l}0.0051 \\
0.0317\end{array}$ & $\begin{array}{l}0.0020 \\
0.0319\end{array}$ & $\begin{array}{l}0.0003 \\
0.0314\end{array}$ & & \\
\hline R-squared & 0.3055 & 0.3551 & 0.3504 & 0.3537 & 0.3256 & 0.3223 & 0.3223 & 0.2480 \\
\hline Adjusted R-squared & 0.1975 & 0.2202 & 0.2323 & 0.2361 & 0.2206 & 0.2339 & 0.2502 & 0.1854 \\
\hline S.E. of regression & 0.0417 & 0.0411 & 0.0408 & 0.0407 & 0.0411 & 0.0408 & 0.0403 & 0.0420 \\
\hline Sum squared resid & 0.0783 & 0.0727 & 0.0733 & 0.0729 & 0.0760 & 0.0764 & 0.0764 & 0.0848 \\
\hline Log likelihood & 97.5076 & 99.4718 & 99.2767 & 99.4114 & 98.2834 & 98.1554 & 98.1553 & 95.3998 \\
\hline Akaike info criterion & -3.3776 & -3.3763 & -3.4067 & -3.4118 & -3.4069 & -3.4398 & -3.4776 & -3.4113 \\
\hline Schwarz criterion & -3.0802 & -3.0045 & -3.0721 & -3.0772 & -3.1095 & -3.1796 & -3.2545 & -3.2254 \\
\hline Hannan-Quinn criter. & -3.2633 & -3.2333 & -3.2780 & -3.2831 & -3.2926 & -3.3398 & -3.3918 & -3.3398 \\
\hline
\end{tabular}

Notes: Those variables which are statistically significant at a level of 0.05 are shown in bold.

Source: Author's calculation. 
The introduction of control variables have revealed a positive correlation between the evolution of stock returns of banks and those of the EuroStoxx 50 index, which would be in line with the assumption that declines in stock returns in this month were not only affecting the EU banking system, but were rather widespread. The significance of domestic exposures tends to suggest that international banks were more affected, in line with the expectation, given the origin of this episode of market turmoil. It is important to note also that neither profitability nor asset quality variables played any role in the evolution of stock returns of our sample of EU banks in August 2015.

\subsection{December 2015 and January 2016}

The second period of decline in stock returns of EU banks covers the last days of 2015 and the first weeks of 2016. In order to be as comprehensive as possible, stock returns from both months are aggregated. The observed stock returns declines were attributed to concerns by market participants on the sustainability of the EU banking system, in an environment of low growth, low interest rates and a significant amount of legacy assets from the global financial crisis. Therefore, it would be expected that those variables referring to bank profitability and asset quality would appear as statistically significant in the results of our regressions, with positive signs in the case of profitability variables (more profitability should translate into positive evolution of stock returns), and negative for asset quality variables (more NPLs and a higher Texas ratio would have a negative impact on bank stock returns). Variables related to the size of banks would then be expected not to be significant.

Similarly to Table 7, the results of these regressions are summarised in Table 9 below.

Table 9.

Results of the regressions on December 2015 and January 2016 stock returns - bank specific variables

\begin{tabular}{ccccc}
\hline \hline Regression & Constant & Size & Profitability & Asset quality \\
\hline 1 & $(+)$ & $(-)$ Total assets & Net interest margin & (-) NPL \\
2 & $(+)$ & $(-)$ Total assets & Net interest margin & $(-)$ Texas ratio \\
3 & $(+)$ & $(-)$ Total assets & ROE & (-) NPL \\
4 & $(+)$ & $(-)$ Total assets & ROE & (-) Texas ratio \\
5 & $(+)$ & $(-)$ Total capital & Net interest margin & (-) NPL \\
6 & $(+)$ & $(-)$ Total capital & Net interest margin & $(-)$ Texas ratio \\
7 & $(+)$ & $(-)$ Total capital & ROE & (-) NPL \\
8 & $(+)$ & $(-)$ Total capital & ROE & (-) Texas ratio \\
9 & $(-)$ & Domestic exposures & Net interest margin & $(-)$ NPL \\
10 & $(-)$ & Domestic exposures & Net interest margin & $(-)$ Texas ratio \\
11 & $(-)$ & Domestic exposures & ROE & NPL \\
12 & $(-)$ & Domestic exposures & ROE & $(-)$ Texas ratio \\
\hline \hline
\end{tabular}

Notes: Those variables which are statistically significant at a level of 0.05 are shown in bold, together with their sign. The sign of the constant is shown only when statistically significant.

In this case, it can be observed how, as expected, asset quality variables tend to be relevant to explain the decreases in EU bank stock returns. Indeed, there is only one regression where the related asset quality variable is not statistically significant. On the contrary, profitability variables are not statistically significant in any of the twelve regressions, hinting at the fact 
that financial market participants were probably more concerned about asset quality than about overall profitability. Interestingly, when compared with the episode in August 2015, domestic exposures are no longer relevant in the regressions, whereas total assets and total capital still remain statistically significant. In this case, asset quality concerns started to gain prevalence in the mind of financial market participants when pricing EU banks stocks.

Contrary to the previous set of regressions, the measures of goodness of fit clearly identify some regressions as having more explanatory power than others. The regressions considering (i) total assets, net interest margin and Texas ratio, (ii) total capital, net interest margin and the Texas ratio, and (iii) total capital, ROE and the Texas ratio, are those with better values of the different measures of goodness of fit. In the three cases, total capital (or total assets) and the Texas ratio are statistically significant, while the variable to capture profitability is not. On the other extreme, those regressions where domestic exposures are introduced as an independent variable are those with lowest values of the measures of goodness of fit.

Table 10 below shows the results of the regressions under equation (2), where control variables are considered. The regression in column 1, which contains the seven independent variables but no control variable, is heteroscedastic, with the net interest margin and the Texas ratio as the only variables which are statistically significant. The introduction of control variables (column 2) makes all the variables in the regression not statistically significant, the same outcome which is found when excluding total capital (column 3), due to its strong correlation with total assets. Dropping total assets from the regression, for the same reason, brings as result that total capital and the change in EuroStoxx50 returns become significant, in both cases with negative sign (column 4). The negative sign of total capital would be counterintuitive, as it would signal that banks with more capital would be penalised by investors. However, it is important to remember that, rather than solvency, total capital reflects here the size of the bank. Besides, the negative sign of the change in the EuroStoxx 50 returns may be interpreted as a divergence between the behaviour of the stock market and of bank stocks (see Table 8 for a contrast with the results on the change in stock returns in August 2015). Dropping the domestic exposures from the regression (column 5) does not meaningfully change the results. Table 6 also highlights the strong correlation between the NPL rate and the Texas ratio, so when the former is dropped from the regression, the Texas ratio becomes statistically significant (column 6). The negative sign is, in this case, expected, as banks with higher Texas ratios would perform worse than those with lower values of the ratio. In terms of goodness-of-fit, the regression in column 6 seems to perform rather well, in comparison with the others. When the Texas ratio is removed, maintaining the NPL rate, heteroscedasticity appears again (column 7). Finally, when total capital is replaced by total assets in the regression in column 6 , total assets and the Texas ratio are the two variables which are statistically significant (column 8).

Table 10.

Results of the regressions on changes in stock returns in December 2015 and January 2016

\begin{tabular}{|c|c|c|c|c|c|c|c|c|}
\hline & (1) & (2) & (3) & (4) & (5) & (6) & (7) & (8) \\
\hline GDP growth & & $\begin{array}{l}1.8753 \\
3.8761\end{array}$ & $\begin{array}{l}1.9404 \\
3.9232\end{array}$ & $\begin{array}{l}1.7873 \\
3.8661\end{array}$ & $\begin{array}{l}1.6363 \\
3.8353\end{array}$ & $\begin{array}{l}1.4720 \\
3.8413\end{array}$ & $\begin{array}{l}2.8506 \\
3.8178\end{array}$ & $\begin{array}{l}1.6493 \\
3.8925\end{array}$ \\
\hline EuroStoxx 50 return & & $\begin{array}{r}-4.7006 \\
5.0979\end{array}$ & $\begin{array}{r}-8.6053 \\
4.3633\end{array}$ & $\begin{array}{r}-7.8412 \\
3.6980\end{array}$ & $\begin{array}{r}\mathbf{- 9 . 1 5 3 7} \\
3.1176\end{array}$ & $\begin{array}{r}\mathbf{- 8 . 5 1 8 7} \\
3.0708\end{array}$ & $\begin{array}{r}-7.7940 \\
3.0441\end{array}$ & $\begin{array}{r}\mathbf{- 8 . 9 3 9} \\
3.4277\end{array}$ \\
\hline Country & & $\begin{array}{r}-0.0142 \\
0.0649\end{array}$ & $\begin{array}{r}-0.0503 \\
0.0606\end{array}$ & $\begin{array}{r}-0.0357 \\
0.0602\end{array}$ & $\begin{array}{r}-0.0303 \\
0.0592\end{array}$ & $\begin{array}{r}-0.0274 \\
0.0593\end{array}$ & $\begin{array}{r}-0.0810 \\
0.0505\end{array}$ & $\begin{array}{r}-0.0429 \\
0.0599\end{array}$ \\
\hline Constant & $\begin{array}{l}0.5030 \\
0.4757\end{array}$ & & & & & & & \\
\hline
\end{tabular}




\begin{tabular}{|c|c|c|c|c|c|c|c|c|}
\hline Total assets & $\begin{array}{l}0.0911 \\
0.0885\end{array}$ & $\begin{array}{l}0.0878 \\
0.0978\end{array}$ & $\begin{array}{r}-0.0499 \\
0.0194\end{array}$ & & & & & $\begin{array}{r}-0.0495 \\
0.0158\end{array}$ \\
\hline Total capital & $\begin{array}{r}-0.1462 \\
0.0885\end{array}$ & $\begin{array}{r}-0.1410 \\
0.0983\end{array}$ & & $\begin{array}{r}-0.0545 \\
0.0192\end{array}$ & $\begin{array}{r}-0.0603 \\
0.0171\end{array}$ & $\begin{array}{r}-0.0557 \\
0.0166\end{array}$ & $\begin{array}{r}-0.0558 \\
0.0171\end{array}$ & \\
\hline Domestic exposures & $\begin{array}{l}0.1055 \\
0.1040\end{array}$ & $\begin{array}{l}0.1078 \\
0.1066\end{array}$ & $\begin{array}{l}0.0495 \\
0.0998\end{array}$ & $\begin{array}{l}0.0630 \\
0.0940\end{array}$ & & & & \\
\hline Net interest margin & $\begin{array}{l}7.2001 \\
3.3929\end{array}$ & $\begin{array}{l}7.0233 \\
3.4933\end{array}$ & $\begin{array}{l}4.1970 \\
2.9201\end{array}$ & $\begin{array}{l}5.2419 \\
2.8677\end{array}$ & $\begin{array}{l}5.0213 \\
2.8309\end{array}$ & $\begin{array}{l}3.8861 \\
2.6421\end{array}$ & $\begin{array}{l}5.6130 \\
2.8514\end{array}$ & $\begin{array}{l}2.8235 \\
2.6946\end{array}$ \\
\hline Return on Equity & $\begin{array}{r}-0.5615 \\
0.3738\end{array}$ & $\begin{array}{r}-0.5463 \\
0.3900\end{array}$ & $\begin{array}{r}-0.4534 \\
0.3893\end{array}$ & $\begin{array}{r}-0.4974 \\
0.3853\end{array}$ & $\begin{array}{r}-0.4587 \\
0.3786\end{array}$ & $\begin{array}{r}-0.3472 \\
0.3656\end{array}$ & $\begin{array}{r}-0.3375 \\
0.3767\end{array}$ & $\begin{array}{r}-0.3043 \\
0.3690\end{array}$ \\
\hline NPL rate & $\begin{array}{r}-0.2156 \\
0.3380\end{array}$ & $\begin{array}{r}-0.2248 \\
0.3483\end{array}$ & $\begin{array}{r}-0.3542 \\
0.3405\end{array}$ & $\begin{array}{r}-0.3240 \\
0.3295\end{array}$ & $\begin{array}{r}-0.3562 \\
0.3239\end{array}$ & & $\begin{array}{r}-0.6824 \\
0.2529\end{array}$ & \\
\hline Texas ratio & $\begin{array}{r}-\mathbf{0 . 2 5 1 4} \\
0.1000\end{array}$ & $\begin{array}{r}-0.2342 \\
0.1234\end{array}$ & $\begin{array}{r}-0.1641 \\
0.1147\end{array}$ & $\begin{array}{r}-0.1900 \\
0.1129\end{array}$ & $\begin{array}{r}-0.1705 \\
0.1084\end{array}$ & $\begin{array}{r}-\mathbf{0 . 2 4 6 8} \\
0.0834\end{array}$ & & $\begin{array}{r}-0.2300 \\
0.0833\end{array}$ \\
\hline $\mathrm{R}$-squared & 0.3838 & 0.3874 & 0.3574 & 0.3756 & 0.3691 & 0.3518 & 0.3336 & 0.3337 \\
\hline Adjusted R-squared & 0.2857 & 0.2561 & 0.2378 & 0.2595 & 0.2687 & 0.2653 & 0.2448 & 0.2448 \\
\hline S.E. of regression & 0.1372 & 0.1401 & 0.1418 & 0.1397 & 0.1389 & 0.1392 & 0.1411 & 0.1411 \\
\hline Sum squared resid & 0.8288 & 0.8239 & 0.8643 & 0.8397 & 0.8484 & 0.8718 & 0.8962 & 0.8961 \\
\hline Log likelihood & 33.8311 & 33.9846 & 32.7407 & 33.4909 & 33.2205 & 32.5155 & 31.7981 & 31.7994 \\
\hline Akaike info criterion & -0.9935 & -0.9225 & -0.9131 & -0.9420 & -0.9700 & -0.9814 & -0.9538 & -0.9538 \\
\hline Schwarz criterion & -0.6933 & -0.5472 & -0.5754 & -0.6042 & -0.6698 & -0.7187 & -0.6911 & -0.6912 \\
\hline Hannan-Quinn criter. & -0.8784 & -0.7786 & -0.7836 & -0.8125 & -0.8549 & -0.8807 & -0.8531 & -0.8531 \\
\hline
\end{tabular}

Notes: Those variables which are statistically significant at a level of 0.05 are shown in bold.

Source: Author's calculation.

When comparing the results of Table 10 with those in Table 9 (which exclude control variables), it can be seen how in both cases independent variables linked to the size of the bank and to asset quality are statistically significant. At the same time, and against the perception on the roots of the decline in stock returns of European banks in these months, it is worth noting that in the two sets of regressions the variables related to bank profitability are not statistically significant. There seems to be also an evolution in the variables explaining the negative investor sentiment from those which were relevant in August 2015. Actually, in this case, the declines in stock returns of EU banks seem to have affected banks of larger size and poorer asset quality, and would not match with the overall trend of the financial markets.

\subsection{June 2016}

The third episode of declines in stock returns of EU banks focuses on the last days of June, following the results of the referendum in the UK on the withdrawal from the EU. In order to cover at least a monthly period, as in the other regressions, stock returns have been taken for the full month of June, even if that means that some of the decreases observed in the last part of the month can be partially compensated. The rationale behind the drop of stock returns was directly linked to the consequences which the withdrawal of the UK from the EU could have, being particularly relevant in the case of banks with significant exposures to the UK. The dataset which is used in this paper does not allow having exposures to individual countries, but exposures to UK can be proxied by size variables: it can be expected that only larger non-UK banks would be 
exposed to the UK and that those with more domestic exposures would be less affected by the outcome of the referendum in the UK. Then, the expected sign to find in the regression would be negative for the variables of total assets and total capital (more exposures to UK would lead to a more negative evolution of stock returns), and positive for the variable related to domestic exposures (stock performance of banks with more domestic exposures should be better than those of banks with less domestic exposures).

The summarised results of these regressions are shown in Table 11 below.

Table 11.

Results of the regressions on changes in stock returns in June 2016 - bank specific variables

\begin{tabular}{ccccc}
\hline \hline Regression & Constant & Size & Profitability & Asset quality \\
\hline 1 & & $(-)$ Total assets & Net interest margin & $(-)$ NPL \\
2 & $(+)$ & $(-)$ Total assets & Net interest margin & $(-)$ Texas ratio \\
3 & & $(-)$ Total assets & $(+)$ ROE & NPL \\
4 & $(+)$ & $(-)$ Total assets & ROE & $(-)$ Texas ratio \\
5 & & $(-)$ Total capital & Net interest margin & $(-)$ NPL \\
6 & $(+)$ & $(-)$ Total capital & Net interest margin & $(-)$ Texas ratio \\
7 & & $(-)$ Total capital & $(+)$ ROE & NPL \\
8 & $(+)$ & $(-)$ Total capital & $(+)$ ROE & $(-)$ Texas ratio \\
9 & $(-)$ & Domestic exposures & Net interest margin & NPL \\
10 & $(-)$ & Domestic exposures & Net interest margin & $(-)$ Texas ratio \\
11 & $(-)$ & Domestic exposures & $(+)$ ROE & NPL \\
12 & $(-)$ & Domestic exposures & $(+)$ ROE & $(-)$ Texas ratio \\
\hline \hline
\end{tabular}

Notes: Those variables which are statistically significant at a level of 0.05 are shown in bold, together with their sign. The sign of the constant is shown only when statistically significant.

Source: Author's calculation.

Even though the results from these regressions are more nuanced than those presented so far, they give rise to interesting interpretations. First, larger banks had a more negative evolution of their stock returns, without a distinction whether the exposures of these banks are domestic or cross-border. Second, while, similarly to the previous regression, net interest margin is not statistically significant in any of the six regressions, ROE is a decisive variable with a positive sign. Third, in terms of the variables related to asset quality, the Texas ratio is more often statistically significant than the rate of NPLs. It is worth noting how both ROE and the Texas ratio use the capital position of banks in their computation (being thus linked to the sustainability of the bank), leading to sounder results that those ratios of a more descriptive nature (like net interest margin or the NPL rate). While the variety of results impedes posing a firm hypothesis of which banks were most affected by the outcome of the referendum in the UK at the end of June 2016, it is possible to signal how those larger banks in terms of assets and capital were more negatively affected and how markets seemed to price the adequate level of capital vis-à-vis the future sustainability challenges for banks in terms of profitability and asset quality.

A look at the values taken by the indicators of goodness of fit provides further insights in the direction hinted above. The three regressions with the lowest values of these indicators are those which combine the variable on size (assets, capital and domestic exposures) with the net interest margin and the NPL rate. That would imply that these two latter variables have limited explanatory power with regards the evolution of stock returns in June 2016. On the other side, 
there are four regressions with substantially higher values for the measures of goodness of fit. They are those using as variables (i) total assets, net interest margin and the Texas ratio, (ii) total assets, ROE and the Texas ratio, (iii) total capital, net interest margin and the Texas ratio, and (iv) total capital, ROE and the Texas ratio. In all cases, the Texas ratio is statistically significant, together with the variable to capture size of the bank. That would tend to signal the importance given to the Texas ratio by investors.

The results of the regressions using bank-specific independent variables are interestingly related to those obtained when control variables are introduced (Table 12). If all the bank-specific variables are introduced in the regression (column 1), the return on equity and the Texas ratio are the only ones which are statistically significant at a level of 0.05 . When the three control variables are added (column 2), only four variables are now statistically significant: GDP growth, changes in EuroStoxx 50 returns, total assets and return on equity. As it has been shown in Table 6, total assets and total capital are strongly correlated, so a natural way to reduce the number of independent variables in the regression would be to remove one of the two. This is shown in columns 3 and 4, having as a consequence that the changes in EuroStoxx 50 returns becomes statistically non-significant and the Texas ratio becomes again statistically significant. Similarly to previous periods, in column 4 , total capital appears with a negative sign, leading to the potentially counterintuitive conclusion that there would be a negative relation between the levels of capital and our dependent variable. Again, total capital must be interpreted here as an indicator of size, so the negative sign in column 4 for total capital should not be read in the context of regulatory capital ratios. Considering the indicators of goodness of fit, we proceed with the regression when total capital is removed. Next, the NPL rate is dropped (column 5) as Table 6 has shown its strong correlation with the Texas ratio as well as due its lack of statistical significance and its counterintuitive sign (positive, implying that more NPLs would lead to higher stock returns). As consequence of the removal of the NPL rate in the regression, the Texas ratio ceases to be statistically significant. Columns 6 and 7 show the regressions once net interest margin and domestic exposures are excluded from the regression, based on their p-values and, in the case of net interest margins, the unexpected negative sign (implying that lower net interest margin should lead to higher stock returns). Column 7 sees how the changes in the EuroStoxx 50 returns are again statistically significant, with a negative sign. Finally, column 8 removes the country dummy as it was not found to be statistically significant in any of the previous regressions. That implies that the Texas ratio is again statistically significant. Values of the indicators of goodness of fit suggest that the explanatory power of the regression is improving with these actions, being the highest in column 8 .

Table 12.

Results of the regressions on changes in stock returns in June 2016

\begin{tabular}{|c|c|c|c|c|c|c|c|c|}
\hline & (1) & (2) & (3) & (4) & (5) & (6) & (7) & (8) \\
\hline GDP growth & & $\begin{array}{l}6.4685 \\
2.0057\end{array}$ & $\begin{array}{l}5.5459 \\
1.9574\end{array}$ & $\begin{array}{l}5.3356 \\
2.0079\end{array}$ & $\begin{array}{l}6.1030 \\
1.9213\end{array}$ & $\begin{array}{l}5.7830 \\
1.8810\end{array}$ & $\begin{array}{l}5.6179 \\
1.8226\end{array}$ & $\begin{array}{l}5.9211 \\
1.8018\end{array}$ \\
\hline EuroStoxx 50 return & & $\begin{array}{r}\mathbf{- 2 0 . 6 2 3 5} \\
8.6404\end{array}$ & $\begin{array}{r}-11.6119 \\
6.7033\end{array}$ & $\begin{array}{r}-6.4310 \\
5.6204\end{array}$ & $\begin{array}{r}-12.7294 \\
6.6924\end{array}$ & $\begin{array}{r}-10.6238 \\
6.2257\end{array}$ & $\begin{array}{r}\mathbf{- 1 2 . 0 9 5 3} \\
5.0931\end{array}$ & $\begin{array}{r}\mathbf{- 1 1 . 9 6 1 9} \\
5.0975\end{array}$ \\
\hline Country & & $\begin{array}{r}-0.0339 \\
0.0367\end{array}$ & $\begin{array}{r}-0.0220 \\
0.0366\end{array}$ & $\begin{array}{r}-0.0200 \\
0.0375\end{array}$ & $\begin{array}{r}-0.0275 \\
0.0366\end{array}$ & $\begin{array}{r}-0.0374 \\
0.0347\end{array}$ & $\begin{array}{r}-0.0360 \\
0.0342\end{array}$ & \\
\hline Constant & $\begin{array}{l}0.6923 \\
0.3760\end{array}$ & & & & & & & \\
\hline Total assets & $\begin{array}{r}-0.0600 \\
0.0628\end{array}$ & $\begin{array}{r}-\mathbf{0 . 1 2 6 9} \\
0.0602\end{array}$ & $\begin{array}{r}-\mathbf{0 . 0 3 1 7} \\
0.0118\end{array}$ & & $\begin{array}{r}-0.0347 \\
0.0116\end{array}$ & $\begin{array}{r}-0.0314 \\
0.0110\end{array}$ & $\begin{array}{r}-0.0336 \\
0.0095\end{array}$ & $\begin{array}{r}-0.0333 \\
0.0095\end{array}$ \\
\hline
\end{tabular}




\begin{tabular}{|c|c|c|c|c|c|c|c|c|}
\hline Total capital & $\begin{array}{l}0.0241 \\
0.0598\end{array}$ & $\begin{array}{l}0.0934 \\
0.0580\end{array}$ & & $\begin{array}{r}-0.0265 \\
0.0116\end{array}$ & & & & \\
\hline Domestic exposures & $\begin{array}{r}-0.0189 \\
0.0691\end{array}$ & $\begin{array}{r}-0.0207 \\
0.0626\end{array}$ & $\begin{array}{l}0.0216 \\
0.0578\end{array}$ & $\begin{array}{l}0.0460 \\
0.0561\end{array}$ & $\begin{array}{l}0.0103 \\
0.0576\end{array}$ & $\begin{array}{l}0.0232 \\
0.0555\end{array}$ & & \\
\hline Net interest margin & $\begin{array}{r}-3.0405 \\
2.7983\end{array}$ & $\begin{array}{r}-5.1714 \\
2.6446\end{array}$ & $\begin{array}{r}-2.3351 \\
2.0086\end{array}$ & $\begin{array}{r}-1.3226 \\
1.9866\end{array}$ & $\begin{array}{r}-1.7119 \\
1.9618\end{array}$ & & & \\
\hline Return on Equity & $\begin{array}{l}\mathbf{0 . 4 4 9 8} \\
0.2117\end{array}$ & $\begin{array}{l}\mathbf{0 . 4 6 6 1} \\
0.1914\end{array}$ & $\begin{array}{l}\mathbf{0 . 4 5 7 3} \\
0.1949\end{array}$ & $\begin{array}{l}\mathbf{0 . 4 6 4 6} \\
0.1989\end{array}$ & $\begin{array}{l}\mathbf{0 . 4 4 9 5} \\
0.1961\end{array}$ & $\begin{array}{l}\mathbf{0 . 3 7 9 3} \\
0.1784\end{array}$ & $\begin{array}{l}\mathbf{0 . 3 7 6 6} \\
0.1767\end{array}$ & $\begin{array}{l}0.3520 \\
0.1754\end{array}$ \\
\hline NPL rate & $\begin{array}{l}0.4101 \\
0.2234\end{array}$ & $\begin{array}{l}0.1523 \\
0.2161\end{array}$ & $\begin{array}{l}0.2651 \\
0.2082\end{array}$ & $\begin{array}{l}0.3135 \\
0.2100\end{array}$ & & & & \\
\hline Texas ratio & $\begin{array}{r}\mathbf{- 0 . 2 3 6 3} \\
0.0709\end{array}$ & $\begin{array}{r}-0.1386 \\
0.0763\end{array}$ & $\begin{array}{r}\mathbf{- 0 . 1 6 6 3} \\
0.0756\end{array}$ & $\begin{array}{r}-\mathbf{0 . 1 7 2 1} \\
0.0775\end{array}$ & $\begin{array}{r}-0.0940 \\
0.0503\end{array}$ & $\begin{array}{r}-0.0961 \\
0.0501\end{array}$ & $\begin{array}{r}-0.0946 \\
0.0495\end{array}$ & $\begin{array}{r}-\mathbf{0 . 1 2 6 8} \\
0.0390\end{array}$ \\
\hline R-squared & 0.4686 & 0.5855 & 0.5600 & 0.5418 & 0.5434 & 0.5355 & 0.5337 & 0.5224 \\
\hline Adjusted R-squared & 0.3840 & 0.4967 & 0.4781 & 0.4565 & 0.4707 & 0.4735 & 0.4830 & 0.4818 \\
\hline S.E. of regression & 0.0904 & 0.0817 & 0.0832 & 0.0849 & 0.0838 & 0.0836 & 0.0828 & 0.0829 \\
\hline Sum squared resid & 0.3595 & 0.2804 & 0.2977 & 0.3100 & 0.3089 & 0.3142 & 0.3154 & 0.3231 \\
\hline Log likelihood & 55.5475 & 62.0120 & 60.4549 & 59.4014 & 59.4925 & 59.0464 & 58.9452 & 58.3254 \\
\hline Akaike info criterion & -1.8288 & -2.0005 & -1.9790 & -1.9385 & -1.9805 & -2.0018 & -2.0364 & -2.0510 \\
\hline Schwarz criterion & -1.5286 & -1.6252 & -1.6413 & -1.6008 & -1.6803 & -1.7391 & -1.8112 & -1.8634 \\
\hline Hannan-Quinn criter. & -1.7137 & -1.8566 & -1.8496 & -1.8090 & -1.8654 & -1.9011 & -1.9500 & -1.9790 \\
\hline
\end{tabular}

Notes: Those variables which are statistically significant at a level of 0.05 are shown in bold.

Source: Author's calculation.

The analysis of the eight regressions in Table 12 reveals the positive role played by the quarterly growth rate of the GDP (in line with, among others, Yang and Tsatsaronis, 2012; O'Neill et al., 2011). Besides, when considering bank-specific variables, total assets, return on equity and the Texas ratio seem to have been the most significant to drive the changes in stock returns, pointing towards the discrimination made by investors against the weakest banks: those of larger size, poorer asset quality and lower profitability, in a context where they also consider the macroeconomic environment. The change in the EuroStoxx 50 returns also appears with negative sign in some of the columns in Table 12, probably indicating a divergence between the behaviour of bank stock returns and those of the financial markets in general. These results are mostly in line with those shown for the regressions without control variables (Table 11), and highlight the interesting fact that direct exposures to the UK did not seem to determine the changes in stock returns in this period, but indicators related to size and to the expected sustainability of banks.

\section{CONCLUSIONS}

Differently to what has been observed in other jurisdictions (i.e., US) or sectors (i.e., nonfinancial corporations), stock prices and returns of EU banks have not recovered to those levels they had at the onset of the global financial crisis in 2008. In this paper, three recent episodes of financial markets turmoil have been analysed, with the dual objective of identifying common characteristics among those banks which stock returns fell the most and of considering whether investor demand on EU banks has evolved or not. Each of these three episodes had different triggers and was perceived as affecting different parts of the EU banking system. 
The results of the regressions presented in this paper tend to show the existence of a common factor driving stock returns of EU banks, according to which banks of larger size have seen their stock returns decrease more than those of banks of smaller size. That was the expected result for the period of August 2015, but not necessarily for the other two episodes. The negative relation between size and stock returns contrasts with the findings of Filbeck et al. (2011) and Yang and Tsatsaronis (2012), where size plays a positive role in terms of stock performance. Whether this is a result of the different geographical and temporal scope of the samples is left open for future research.

At the same time, there has also been an evolution on the perception of EU banks by financial market participants. The first period considered (August 2015) also saw market-wide declines in stock returns while the turmoil in the other two periods (December 2015 and January 2016, and June 2016) can be characterised as focused mostly on EU bank stocks. Actually, since December 2015, the Texas ratio, as a variable capturing asset quality, has gained importance in characterising those banks which stock returns have fallen more sharply. The variables capturing profitability are only relevant in the last period (June 2016) and only to the extent that it relates to the capital position of banks (return on equity). The lack of significance of profitability variables to explain the evolution of bank stock returns may also be further explored, as it would be rather counterintuitive. Asset quality and profitability are two of the characteristics identified by Baker and Wurgler (2007) and Irresberger et al. (2015) as common to those banks more sensitive to waves of investor sentiment.

In general terms, the short period of time selected for this paper (one or two months) may explain why some of the results seem to contradict other results in the academic literature which consider longer periods of time in their analysis, like Cabrera et al. (2016), Chan-Lau et al. (2012), Filbeck et al. (2011), or Yang and Tsatsaronis (2012). Besides, contrary to the recent academic literature, which is focused on the years of highest severity of the global financial crisis, the periods under consideration in this paper are situated in a context of recovery from the most severe months of the global financial crisis. So, it is possible that the bank-specific variables driving bank stock returns are slightly different during a period of acute financial turmoil than during a more targeted period of turmoil, in a context of recovery. More research, in the line of Filbeck et al. (2011), may be conducted to check this intuition.

Finally, entering into the policy arena, in the sermon by Edwards (1741), the Devil stood ready to prey on the weakest souls. Similarly, investor demand on EU banks has evolved in a way which in June 2016 showed their distrust on those EU banks perceived to be weaker, in terms of asset quality or profitability. The necessary repair of those weak EU banks seems to be an area of further consideration by policymakers in the EU, as it seems to impede the necessary recovery from the global financial crisis. After all, the sermon by Edwards (1741) was a crucial element in the so-called "Great Awakening", which set a new frame of personal commitment in the religious domain, after decades of more relaxed attitudes.

\section{Acknowledgments}

The views expressed in this paper are those of the author and do not necessarily represent the views of the European Systemic Risk Board, any of its Member Institutions or the ESRB Secretariat. Many thanks to Magdalena Grothe and Nikolas Mayer for the rich discussions and preliminary work on this topic, and to Pavol Jurca for his comments. Finally, comments by two anonymous referees are gratefully acknowledged as they have contributed to significantly improve the quality of the paper. Any remaining error is my own. 


\section{References}

Aebi V., Sabato G., Schmid M. (2012). Risk management, corporate governance, and bank performance in the financial crisis. Journal of Banking \& Finance, 36(12): 3212-3226. doi: /10.1016/j.jbankfin.2011.10.020.

Baker M., Wurgler J. (2006). Investor sentiment and the cross-section of stock returns. Journal of Finance, 61(4): 1645-1680. doi:10.1111/j.1540-6261.2006.00885.x.

Baker M., Wurgler J. (2007). Investor sentiment in the stock market. Journal of Economic Perspectives, 21(2): 129-152. doi: 10.1257/jep.21.2.129.

Beck R., Jakubik P., Piloiu A. (2013). Non-performing loans: What matters in addition to the economic cycle? ECB Working Paper Series No. 1515.

Beltratti A., Stulz R.M. (2012). The credit crisis around the globe: why did some banks perform better? Journal of Financial Economics, 105(1): 1-17. doi: 10.1016/j.jfineco.2011.12.005.

Bondt W.F.M. De, Muradoglu Y.G., Shefrin H., Staikouras S.K. (2015). Behavioral finance: quo vadis? Journal of Applied Finance, 19(2): 7-21.

Burr Williams J. (1938). The theory of investment value. Cambridge, Mass: Harvard University Press.

Byrne A., Brooks M. (2008). Behavioral finance: theories and evidence. The Research Foundation of CFA Institute Literature Review. doi: 10.2470/rflr.v3.n1.1.

Cabrera M., Dwyer G.P., Samartín-Saénz M. (2016). Government finances and bank bailouts: Evidence from European stock markets, Journal of Empirical Finance 39(B): 169-179. doi: 10.1016/j.jempfin.2016.06.005.

Cao C., Petrasek L. (2014). Liquidity risk in stock returns: An event-study perspective. Journal of Banking \& Finance, 45: 72-83. doi: 10.1016/j.jbankfin.2013.09.020.

Castrén O., Fitzpatrick T., Sydow M. (2006). What drives EU banks' stock returns? Bank-level evidence using the dynamic dividend-discount model. ECB Working Paper Series No. 677.

Chan-Lau J., Liu E., Schmittmann J. (2012). Equity returns in the banking sector in the wake of the Great Recession and the European sovereign debt crisis. IMF Working Paper WP/12/174

Clarke J., Jandik T., Mandelker G. (2001). The efficient markets hypothesis in Arffa, R. (ed.): Expert financial planning: advice from industry leaders. New York: Wiley.

Cooper M., Jackson III W., Patterson G. (2003). Evidence of predictability in the cross-section of bank stock returns. Journal of Banking \& Finance 27(5): 817-850. doi: 10.1016/S0378-4266(01)00263-1.

Damodaran A. (2011). Equity Risk Premiums (ERP): determinants, estimation and implications - The 2011 Edition. New York University - Stern School of Business.

Demirgüç-Kunta A., Huizinga H. (2013). Are banks too big to fail or too big to save? International evidence from equity prices and CDS spreads. Journal of Banking and Finance, 37(3): 875-894. doi: 10.1016/j.jbank fin.2012.10.010.

Edwards J. (1741). Sinners in the hands of an angry God, a sermon preached at Enfield. Retrieved 19.05.2017 from http://digitalcommons.unl.edu/cgi/viewcontent.cgi?article $=1053 \&$ context=etas.

Fahlenbrach R., Prilmeier R., Stulz R.M. (2012). This time is the same: Using bank performance in 1998 to explain bank performance during the recent financial crisis. Journal of Finance, 67(6): 2139-2185.

Fama E.F. (1970). Efficient capital markets: a review of theory and empirical work. Journal of Finance, 25(2): 383-417.

Fama E.F. (1998). Market efficiency, long-term returns, and behavioral finance. Journal of Finance, 49(3): $283-306$.

Filbeck G., Preece D., Zhao X. (2011). Top performing banks: size effect and economic cycles. Journal of Investing, 20(1): 19-32. doi: 10.3905/joi.2011.20.1.019.

Fisher I. (1930). The theory of interest. New York: The Macmillan Co.

International Monetary Fund (2016). Global Financial Stability Report, chapter 1. October.

Irresberger F., Mühlnickel J., Weiß G.N.F. (2015). Explaining bank stock performance with crisis sentiment, Journal of Banking \& Finance, 59: 311-329. doi: 10.1016/j.jbankfin.2015.06.001.

Jegadeesh N., Titman S. (1993). Returns to buying winners and selling losers: implications for stock market efficiency. Journal of Finance, 48(1): pp 65-91. doi: 10.2307/2328882.

Liadakia A., Gaganis C. (2010). "Efficiency and stock performance of EU banks: is there a relationship? Omega, 38(5): 254-259. doi: 10.1016/j.omega.2008.09.003.

Merton R.C. (1974). On the pricing of corporate debt: The risk structure of interest rates. Journal of Finance, 29(2): 449-470. doi: 10.2307/2978814.

Nagel S., Purnanandam A. (2015). Bank risk dynamics and distance to default. Working Paper University of Michigan.

O’Neill J., Stupnytska A., Wrisdale J. (2011). Linking GDP growth and equity returns. Goldman Sachs Asset Management Monthly Insights.

Salvador C. (2017). Effect of signals of bank ratings on stock returns before and during the financial crisis. The Spanish Review of Financial Economics, 15(1): 1-11. doi: 10.1016/j.srfe.2017.01.002. 
Samuelson P. (1965). Proof that properly anticipated prices fluctuate randomly. Industrial Management Review, 6(2): 41-49.

Schäfer A., Schnabel I., Weder di Mauro B. (2013). Financial sector reform after the crisis: has anything happened? CEPR Discussion Paper No 9502.

Schiller R.J. (2003). From efficient markets theory to behavioral finance. Journal of Economic Perspectives, 17(1): 83-104.

Schweitzer R. (1989). How do stock returns react to special events? Business Review of the Federal Reserve Bank of Philadelphia, issue July/August.

Shleifer A. (2000). Inefficient markets: an introduction to behavioural finance. Oxford: Oxford University Press.

Steiger F. (2008). The validity of company valuation using discounted cash flow methods. European Business School.

Tetlock P.C. (2007). Giving content to investor sentiment: the role of media in the stock market. Journal of Finance, 62(3): 1139-1168. doi: 10.1111/j.1540-6261.2007.01232.x.

Weigand R. (2016). The performance and risk of banks in the U.S., Europe and Japan post-financial crisis. Investment Management and Financial Innovations, 13(4): 75-93. doi: 10.21511/imfi.13(4).2016.07.

Yang J., Tsatsaronis K. (2012). Bank stock returns, leverage and the business cycle. BIS Quarterly Review, March. 


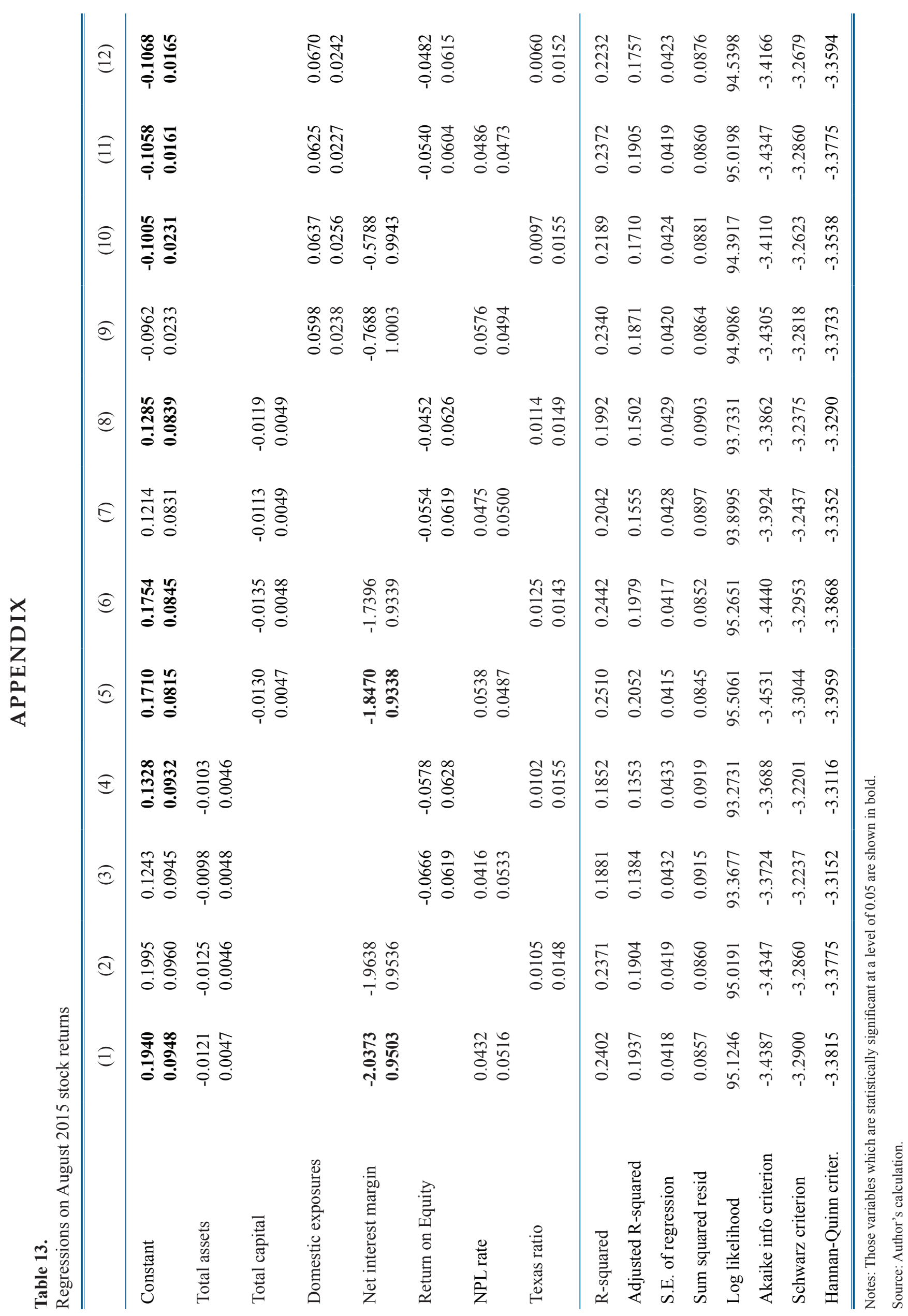




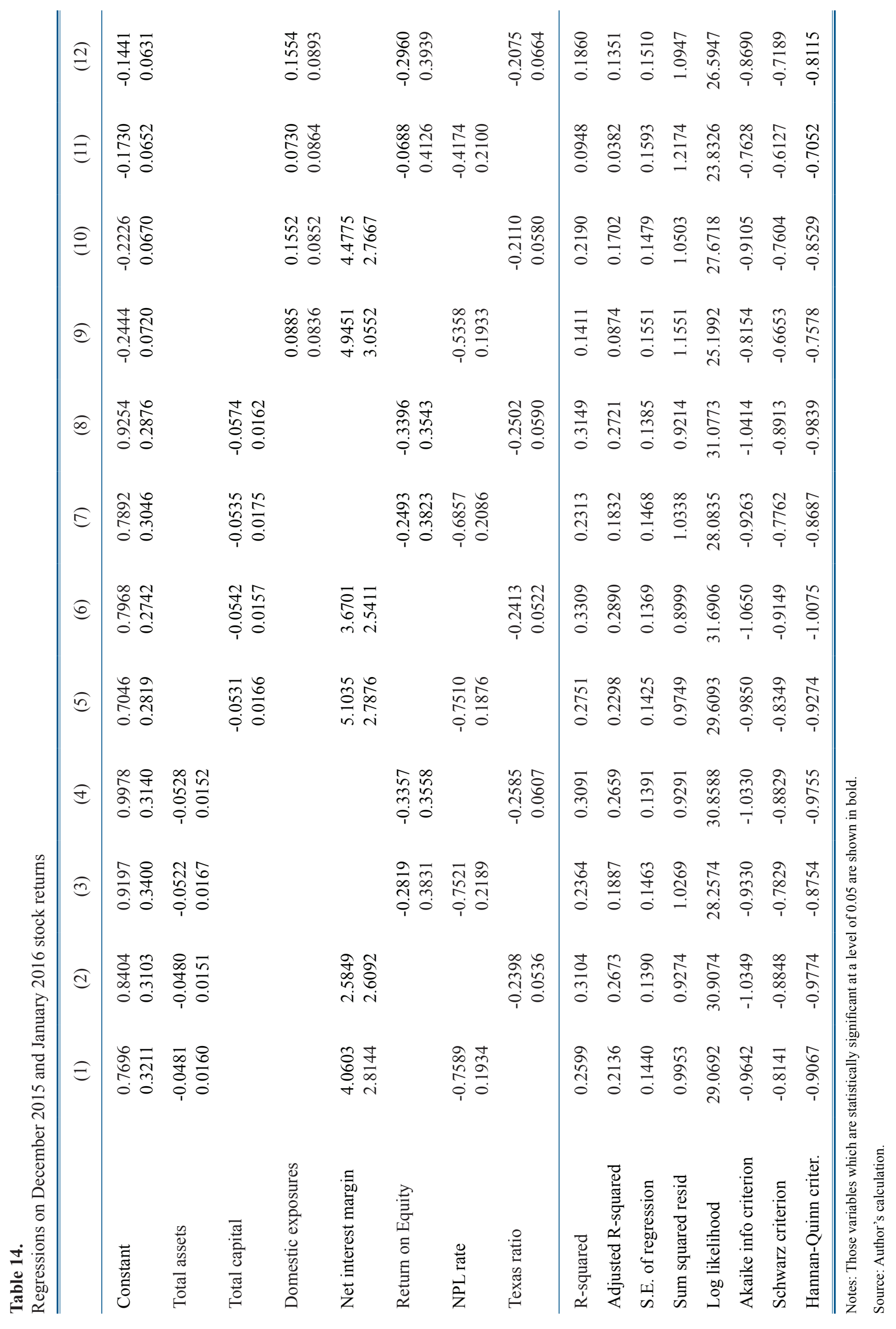




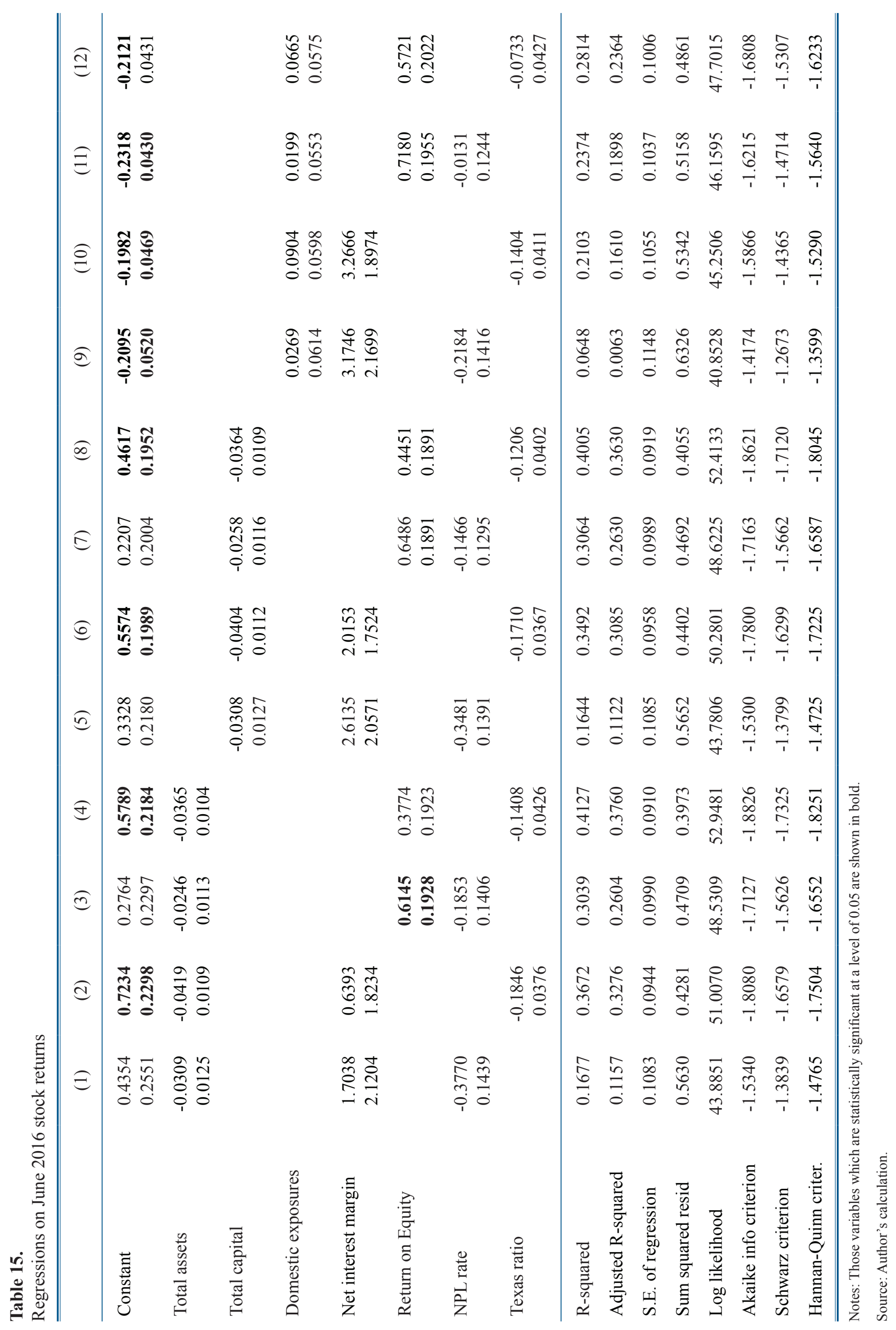

